\title{
STRUKTURA POLA OPADÓW POLSKI NA TLE WARUNKÓW CYRKULACYJNYCH
}

\author{
ZBIGNIEW KOMAR \\ Instytut Geografii Fizycznej i Kształtowania Środowiska Przyrodniczego, \\ Uniwersytet im. Adama Mickiewicza w Poznaniu
}

\begin{abstract}
The way circulation factors influence the spatial structure of the precipitation area in Poland was studied on the basis of everyday pluviometric data from 31 metrological stations as well as a circulation catalogue published by M. Stępniewska-Podrażka. The analysis covered all 7-day-long or longer periods which displayed the same type of circulation in the years 1951-1990. The pluviometric data gathered made it possible to characterise the pluviometric regimes for each town in the specified periods taking account of 3 factors: total precipitation, frequency of precipitation and intensity of precipitation. The study focused on pluviometric similarities between neighbouring points (stations) under specified conditions of atmospheric circulation. When considering matters related to the objective of the study, account was taken of the elements of the graph theory which not only made it possible to graphically represent the directions of similarity research but also showed the degree of consistency between pluviometric similarity networks from a statistical point of view.

The research uncovered some particular features of structural organisation of the precipitation area depending on the conditions of atmospheric circulation:

- Variation in similarity within the precipitation areas is disturbed to a different degree The number of similar relations in constructed graph networks varied between 9 and 75 .

- Cases of perfect similarity can be observed only under anti-cyclonic circulation and were present in SEa, $\mathrm{Sa}$ and $\mathrm{Oa}$ circulation types.

- The degree of similarity within the precipitation area varies depending on the character of circulation. The mean frequency with which precipitation similarities were identified along studied edges is at its lowest under cyclonic circulation and at its highest under anti-cyclonic conditions.

- When analyzed by seasons, the frequency of pluviometric precipitation similarity along specified relation lines was lower in the warm half-year under cyclonic, intermediate and anti-cyclonic circulation conditions.

The graph method of studying structural features of the precipitation area used in this paper has proved to be a useful and effective research tool especially when applied to analyses of spatial relations. Presented examples of graphs are a more or less clear indication that the spatial structure of the precipitation area in Poland studied from the perspective of pluviometric similarity relations is determined by circulation factors with the spatial scope of this influence depending on the season.
\end{abstract}

Keywords: Poland, atmospheric precipitation, atmospheric circulation

\section{WPROWADZENIE}

W literaturze klimatologicznej zagadnienie związków zachodzących między cyrkulacją atmosferyczną i elementami pogody oraz klimatu jest dość powszechne i stanowi przedmiot wielu wnikliwych studiów badawczych. Uwaga ta odnosi się zarówno do literatury obcej, jak i rodzimej. W naszym kraju 
powody zainteresowania tą problematyką wynikają ze słusznego przekonania, iż o czasoprzestrzennej zmienności zjawisk pogodowych na obszarze Polski decyduja w znacznej mierze procesy synoptyczne zachodzące nie tylko nad terytorium Polski, ale przede wszystkim nad europejskim sektorem umiarkowanych szerokości geograficznych. Charakter stanów pogody, ich trwałość, następstwo czy wreszcie dynamika zmian w czasie i przestrzeni zależą bowiem od rodzaju układów barycznych, właściwości mas powietrznych oraz procesów zachodzących na frontach atmosferycznych, czyli tych czynników, dla rozpoznania których pożądana jest analiza w tzw. skali synoptycznej. Dynamiczne cechy klimatu Polski są na ogół kształtowane przez peryferyjne części niżów i wyżów, jako że trajektorie ruchu ich centrów przebiegają zwykle poza granicami naszego kraju. Położenie geograficzne układów barycznych, a ściślej ich przestrzenna orientacja względem obszaru Polski nadaje kierunek ruchom powietrza w naszym regionie, natomiast wartości poziomego gradientu ciśnienia wpływają na prędkość przemieszczania się mas powietrznych. Z kierunkiem ich napływu związany jest między innymi transport pary wodnej oraz ciepła i chłodu. Charakter stref kontaktu różnych mas powietrznych, czyli właściwości stref frontowych decydują często o intensywności i trwałości takich elementów pogody, jak zachmurzenie, opady czy stosunki termiczne. W świetle tych stwierdzeń zasadne są próby wykrycia oraz parametryzacji związków i współzależności poszczególnych elementów meteorologicznych z szeroko pojętymi procesami cyrkulacyjnymi.

\section{CEL I ZAKRES OPRACOWANIA}

Celem niniejszego opracowania jest próba określenia wpływu elementów cyrkulacji atmosfery na strukturę przestrzenną pola opadów atmosferycznych Polski. Istotnym zagadnieniem jest również zwrócenie uwagi na sezonowe nasilenie wspomnianych zależności.

Używane w niniejszym opracowaniu sformułowanie struktura pola opadów obejmuje podobieństwo reżimu opadów i jest wyrażone przestrzennym układem pozytywnych i negatywnych relacji pluwiometrycznego podobieństwa zachodzących między sąsiednimi punktami pola. Innymi słowy, przedmiotem przeprowadzonej analizy były sytuacje, kiedy w konkretnych warunkach cyrkulacji obok relacji podobieństwa opadowego w badanym polu występują strefy tego podobieństwa pozbawione. Przestrzenny rozkład oraz częstość występowania podobieństwa opadowego w obrębie wspomnianych obszarów należy uznać za pewną swoistą cechę struktury pola opadów atmosferycznych.

W opracowaniu wykorzystano klasyfikację typów cyrkulacji według Lityńkiego (1969), w której o konkretnym typie cyrkulacji decydują trzy wskaźniki: cyrkulacji strefowej (Ws), cyrkulacji południkowej (Wp) oraz ciśnienia (Cp). 
Dwa pierwsze określają kierunek napływu mas powietrza nad Polskę i obliczane są dla obszaru centralnej Europy, ograniczonego południkami $0^{\circ}$ i $35^{\circ} \mathrm{E}$ oraz równoleżnikami $40^{\circ}$ i $65^{\circ} \mathrm{N}$. Natomiast wskaźnik ciśnienia, którego wartość przyjmuje się dla miejsca pokrywającego się z położeniem Warszawy, decyduje o charakterze cyrkulacji. Analizując krzywe rozkładu wskaźników cyrkulacji Ws i Wp, wyróżniono osiem grup cyrkulacyjnych oznaczonych symbolami literowymi zgodnie z kierunkiem geograficznym napływu mas powietrza oraz grupę sytuacji charakteryzujących się brakiem wyraźnej adwekcji mas powietrza oznaczonych jako sytuacje „0”. W poszczególnych grupach kierunkowych wydzielono trzy rodzaje typów cyrkulacji ze względu na wartość ciśnienia. W sumie uzyskano 27 typów cyrkulacji:

- cyrkulacja cyklonalna: Nc, NEc, Ec, SEc, Sc, SWc, Wc, NWc, Oc,

- cyrkulacja pośrednia: No, NEo, Eo, SEo, So, SWo, Wo, Wo, Oo,

- cyrkulacja antycyklonalna: Na, NEa, Ea, SEa, Sa, SWa, Wa, NWa, Oa.

W opracowaniu analizie poddano wszystkie okresy co najmniej 7-dniowe, które w wieloleciu 1951-1990 charakteryzowały się wystąpieniem tego samego typu cyrkulacji. Należy zaznaczyć, że przy założeniu zachodzących na przełomie doby zmian typów cyrkulacji uwzględnienie zbyt krótkich okresów, wywoływałoby trudny do uchwycenia wpływ typu poprzedzającego na charakter cyrkulacji atmosferycznej wyodrębnionego ciagu czasowego. Uwzględnienie dłuższych sekwencji dni o tym samym typie cyrkulacji zmniejsza w pewnym stopniu znaczenie typu poprzedzającego oraz jednocześnie daje pewność zaistnienia tych samych warunków cyrkulacyjnych na całym badanym terytorium Polski. Opierając się na kalendarzu sytuacji synoptycznych, opublikowanym przez Marię Stępniewską-Podrażkę (1991), wyodrębniono 274 okresy cyrkulacyjnie podobne, przy czym 130 odnotowano w ciepłym okresie roku, a $144 \mathrm{w}$ półroczu chłodnym (tab. 1). Biorąc pod uwagę charakter cyrkulacji, należy zauważyć, iż w utworzonym zbiorze jednolitych pod względem warunków synoptycznych ciągów dni najliczniejszą grupę stanowią sekwencje z cyrkulacją o charakterze antycyklonalnym (147). Przypadków z cyrkulacją cyklonalną odnotowano 90 , a z cyrkulacją pośrednią 37 . W przypadku sytuacji cyklonalnych i antycyklonalnych większa liczba odnotowanych ciaggów dni synoptycznie podobnych przypada na półrocze chłodne (odpowiednio 50 i 77 zdarzeń), a mniejsza na ciepły okres roku (40 i 70). Z kolei w przypadku sekwencji dni charakteryzujących się cyrkulacją pośrednią stwierdzono odwrotny sezonowy rozkład liczby zdarzeń. Dominującym zbiorem są ciagi dni cyrkulacyjnie podobnych, występujące od maja do października, których zanotowano 20, a mniejszość stanowią zdarzenia zidentyfikowane od listopada do kwietnia (17) - tabela 1.

W kolejnym kroku postępowania badawczego dla wszystkich wyróżnionych okresów zgromadzono dane dotyczące stosunków opadowych. Wykorzystano 
Tabela 1. Liczba okresów z takim samym typem cyrkulacji i trwających co najmniej 7 lub więcej kolejnych dni w warunkach cyrkulacji o charakterze cyklonalnym (a), pośrednim (b), antycyklonalnym (c). Wartości z lat 1951-1990

Table 1. Number of periods lasting 7 or more consecutive days with the same type of circulation under conditions of cyclonic (a), intermediate (b) and anti-cyclonic (c) circulation. Values for $1951-1990$

a

\begin{tabular}{|c|c|c|c|c|c|c|c|}
\hline \multirow{2}{*}{$\begin{array}{l}\text { Typ } \\
\text { cyrkulacji }\end{array}$} & \multicolumn{6}{|c|}{$\begin{array}{l}\text { Liczba przypadków } \\
\text { przypadająca na poszczególne okresy roku }\end{array}$} & \multirow[b]{2}{*}{ Rok } \\
\hline & $\begin{array}{l}\text { wiosna } \\
\text { [III-V] }\end{array}$ & $\begin{array}{c}\text { lato } \\
\text { [VI-VIII] }\end{array}$ & $\begin{array}{l}\text { jesień } \\
{[\mathrm{IX}-\mathrm{XI}]}\end{array}$ & $\begin{array}{c}\text { zima } \\
{[\mathrm{XII-II}]}\end{array}$ & $\begin{array}{c}\text { półrocze } \\
\text { ciepłe } \\
{[\mathrm{V}-\mathrm{X}]}\end{array}$ & $\begin{array}{l}\text { półrocze } \\
\text { chłodne } \\
\text { [XI-IV] }\end{array}$ & \\
\hline $\mathrm{Nc}$ & 1 & 3 & 1 & 3 & 4 & 4 & 8 \\
\hline $\mathrm{NEc}$ & 4 & 5 & 3 & 2 & 10 & 4 & 14 \\
\hline Ec & 2 & 3 & 0 & 0 & 4 & 1 & 5 \\
\hline SEc & 1 & 1 & 1 & 2 & 3 & 2 & 5 \\
\hline Sc & 2 & 0 & 4 & 2 & 4 & 4 & 8 \\
\hline SWc & 2 & 0 & 4 & 9 & 1 & 14 & 15 \\
\hline Wc & 1 & 1 & 2 & 4 & 2 & 6 & 8 \\
\hline NWc & 4 & 8 & 4 & 2 & 9 & 9 & 18 \\
\hline \multirow[t]{2}{*}{ Oc } & 3 & 2 & 0 & 4 & 3 & 6 & 9 \\
\hline & 20 & 23 & 19 & 28 & 40 & 50 & 90 \\
\hline
\end{tabular}

b

\begin{tabular}{lccccccc}
\hline \multirow{2}{*}{$\begin{array}{c}\text { Typ } \\
\text { cyrkulacji }\end{array}$} & \multicolumn{7}{c}{ Liczba przypadków } \\
\cline { 2 - 7 } & wiosna & lato & jesień & zima & $\begin{array}{c}\text { półrocze } \\
\text { ciepłe } \\
{[\text { [V-X] }}\end{array}$ & $\begin{array}{c}\text { półrocze } \\
\text { chłodne } \\
{[\mathrm{XI} \text {-IV] }}\end{array}$ & Rok \\
\hline No & 0 & 0 & 0 & 0 & 0 & 0 & 0 \\
NEo & 0 & 3 & 0 & 0 & 3 & 0 & 3 \\
Eo & 3 & 0 & 0 & 0 & 2 & 1 & 3 \\
SEo & 2 & 0 & 0 & 3 & 0 & 5 & 5 \\
So & 1 & 1 & 4 & 1 & 3 & 4 & 7 \\
SWo & 1 & 0 & 2 & 3 & 2 & 4 & 6 \\
Wo & 0 & 4 & 3 & 0 & 7 & 0 & 7 \\
NWo & 0 & 2 & 1 & 2 & 2 & 3 & 5 \\
Oo & 0 & 0 & 1 & 0 & 1 & 0 & 1 \\
& 7 & 10 & 11 & 9 & 20 & 17 & 37 \\
\hline
\end{tabular}




\begin{tabular}{|c|c|c|c|c|c|c|c|}
\hline \multirow{2}{*}{$\begin{array}{c}\text { Typ } \\
\text { cyrkulacji }\end{array}$} & \multicolumn{6}{|c|}{$\begin{array}{l}\text { Liczba przypadków } \\
\text { przypadająca na poszczególne okresy roku }\end{array}$} & \multirow[b]{2}{*}{ Rok } \\
\hline & $\begin{array}{l}\text { wiosna } \\
\text { [III-V] }\end{array}$ & $\begin{array}{c}\text { lato } \\
\text { [VI-VIII] }\end{array}$ & $\begin{array}{l}\text { jesień } \\
{[\mathrm{IX}-\mathrm{XI}]}\end{array}$ & $\begin{array}{l}\text { zima } \\
\text { [XII-II] }\end{array}$ & $\begin{array}{c}\text { półrocze } \\
\text { ciepłe } \\
{[\mathrm{V}-\mathrm{X}]}\end{array}$ & $\begin{array}{c}\text { półrocze } \\
\text { chłodne } \\
\text { [XI-IV] }\end{array}$ & \\
\hline $\mathrm{Na}$ & 3 & 2 & 1 & 2 & 4 & 4 & 8 \\
\hline NEa & 6 & 9 & 2 & 2 & 14 & 5 & 19 \\
\hline Ea & 7 & 6 & 2 & 4 & 10 & 9 & 19 \\
\hline SEa & 13 & 2 & 9 & 11 & 9 & 26 & 35 \\
\hline Sa & 2 & 0 & 2 & 4 & 1 & 7 & 8 \\
\hline SWa & 2 & 5 & 0 & 4 & 6 & 5 & 11 \\
\hline Wa & 1 & 3 & 6 & 3 & 7 & 6 & 13 \\
\hline NWa & 1 & 2 & 4 & 1 & 6 & 2 & 8 \\
\hline \multirow[t]{2}{*}{$\mathrm{Oa}$} & 4 & 5 & 6 & 11 & 13 & 13 & 26 \\
\hline & 39 & 34 & 32 & 42 & 70 & 77 & 147 \\
\hline
\end{tabular}

materiał źródłowy obejmujący codzienne dane pluwiometryczne dla 31 stacji meteorologicznych (tab. 2). Dobór stacji podporządkowano zasadzie ich w miarę równomiernego rozmieszczenia (ryc. 1) oraz możliwie szerokiej reprezentatywności identyfikowanych na obszarze Polski regionów fizycznogeograficznych i klimatycznych.

Zgromadzone dane opadowe pozwoliły scharakteryzować w każdej miejscowości reżim pluwiometryczny wyróżnionych okresów z punktu widzenia trzech wskaźników: sumy opadów wyrażonej w mm, deszczowości wyrażonej w \%, jako stosunek liczby dni z opadem do wszystkich dni w danym okresie, oraz obfitości, rozumianej jako średnia ilość opadu przypadająca na dzień z opadem, wyrażonej w mm na dzień z opadem. Wskaźniki te pod względem jakościowym i ilościowym charakteryzują różne wycinki reżimu opadów, a analizowane jednocześnie w sposób kompleksowy opisują charakter opadów atmosferycznych określonej jednostki badawczej.

Zasadnicze kwestie związane z celem podjętych badań rozpatrzono, uwzględniając elementy teorii grafów. Relacje podobieństwa zachodzące w polu opadów między sąsiednimi stacjami były badane dla każdego okresu z zastosowaniem miary podobieństwa, za jaką uznano odległość geometryczną w przestrzeni wielocechowej, w tym przypadku trójcechowej. Algorytm obliczeniowy związany z obliczeniem wspomnianych odległości geometrycznych uwzględniał wszystkie 274 okresy oraz reżim opadowy każdej stacji opisany trzema cechami. Ponieważ każdy ze wskaźników wyrażony jest w innym mianie $(\mathrm{mm}, \%, \mathrm{~mm} /$ dzień z opadem), sprowadzono je do postaci porównywalnej. Dokonano tego przez 
Tabela 2. Stacje meteorologiczne uwzględnione w opracowaniu

Table 2. Meteorological stations taken into account in the study

\begin{tabular}{|c|c|c|c|c|}
\hline \multirow{2}{*}{ Lp. } & \multirow{2}{*}{ Nazwa stacji } & \multirow{2}{*}{$\begin{array}{l}\text { Wysokość } \\
\text { [m n.p.m.] }\end{array}$} & \multicolumn{2}{|c|}{ Współrzędne geograficzne } \\
\hline & & & $\lambda E$ & $\varphi \mathrm{N}$ \\
\hline 1 & Łeba & 2 & $17^{\circ} 32^{\prime}$ & $54^{\circ} 45^{\prime}$ \\
\hline 2 & Koszalin & 32 & $16^{\circ} 09^{\prime}$ & $54^{\circ} 12^{\prime}$ \\
\hline 3 & Elblag & 38 & $19^{\circ} 26^{\prime}$ & $54^{\circ} 10^{\prime}$ \\
\hline 4 & Suwałki & 184 & $22^{\circ} 57^{\prime}$ & $54^{\circ} 08^{\prime}$ \\
\hline 5 & Kętrzyn & 108 & $21^{\circ} 22^{\prime}$ & $54^{\circ} 05^{\prime}$ \\
\hline 6 & Świnoujście & 1 & $14^{\circ} 14^{\prime}$ & $53^{\circ} 55^{\prime}$ \\
\hline 7 & Chojnice & 172 & $17^{\circ} 33^{\prime}$ & $53^{\circ} 42^{\prime}$ \\
\hline 8 & Wałcz & 111 & $16^{\circ} 28^{\prime}$ & $53^{\circ} 17^{\prime}$ \\
\hline 9 & Witosław & 110 & $17^{\circ} 29^{\prime}$ & $53^{\circ} 15^{\prime}$ \\
\hline 10 & Białystok & 148 & $23^{\circ} 10^{\prime}$ & $53^{\circ} 06^{\prime}$ \\
\hline 11 & Mława & 147 & $20^{\circ} 21^{\prime}$ & $53^{\circ} 06^{\prime}$ \\
\hline 12 & Płock & 63 & $19^{\circ} 44^{\prime}$ & $52^{\circ} 32^{\prime}$ \\
\hline 13 & Poznań & 86 & $16^{\circ} 50^{\prime}$ & $52^{\circ} 25^{\prime}$ \\
\hline 14 & Słubice & 21 & $14^{\circ} 36^{\prime}$ & $52^{\circ} 21^{\prime}$ \\
\hline 15 & Warszawa & 106 & $20^{\circ} 58^{\prime}$ & $52^{\circ} 10^{\prime}$ \\
\hline 16 & Terespol & 133 & $23^{\circ} 37^{\prime}$ & $52^{\circ} 04^{\prime}$ \\
\hline 17 & Leszno & 91 & $16^{\circ} 32^{\prime}$ & $51^{\circ} 50^{\prime}$ \\
\hline 18 & Łódź & 187 & $19^{\circ} 24^{\prime}$ & $51^{\circ} 44^{\prime}$ \\
\hline 19 & Kalisz & 140 & $18^{\circ} 05^{\prime}$ & $51^{\circ} 44^{\prime}$ \\
\hline 20 & Puławy & 142 & $21^{\circ} 58^{\prime}$ & $51^{\circ} 25^{\prime}$ \\
\hline 21 & Wieluń & 195 & $18^{\circ} 34^{\prime}$ & $51^{\circ} 13^{\prime}$ \\
\hline 22 & Wrocław & 120 & $16^{\circ} 53^{\prime}$ & $51^{\circ} 06^{\prime}$ \\
\hline 23 & Jelenia Góra & 342 & $15^{\circ} 48^{\prime}$ & $50^{\circ} 54^{\prime}$ \\
\hline 24 & Kielce & 268 & $20^{\circ} 37^{\prime}$ & $50^{\circ} 51^{\prime}$ \\
\hline 25 & Zamość & 212 & $23^{\circ} 15^{\prime}$ & $50^{\circ} 42^{\prime}$ \\
\hline 26 & Kłodzko & 316 & $16^{\circ} 37^{\prime}$ & $50^{\circ} 26^{\prime}$ \\
\hline 27 & Rzeszów & 200 & $22^{\circ} 03^{\prime}$ & $50^{\circ} 06^{\prime}$ \\
\hline 28 & Racibórz & 190 & $18^{\circ} 13^{\prime}$ & $50^{\circ} 05^{\prime}$ \\
\hline 29 & Kraków & 237 & $19^{\circ} 58^{\prime}$ & $50^{\circ} 04^{\prime}$ \\
\hline 30 & Lesko & 420 & $22^{\circ} 21^{\prime}$ & $49^{\circ} 28^{\prime}$ \\
\hline 31 & Zakopane & 857 & $19^{\circ} 57^{\prime}$ & $49^{\circ} 18^{\prime}$ \\
\hline
\end{tabular}




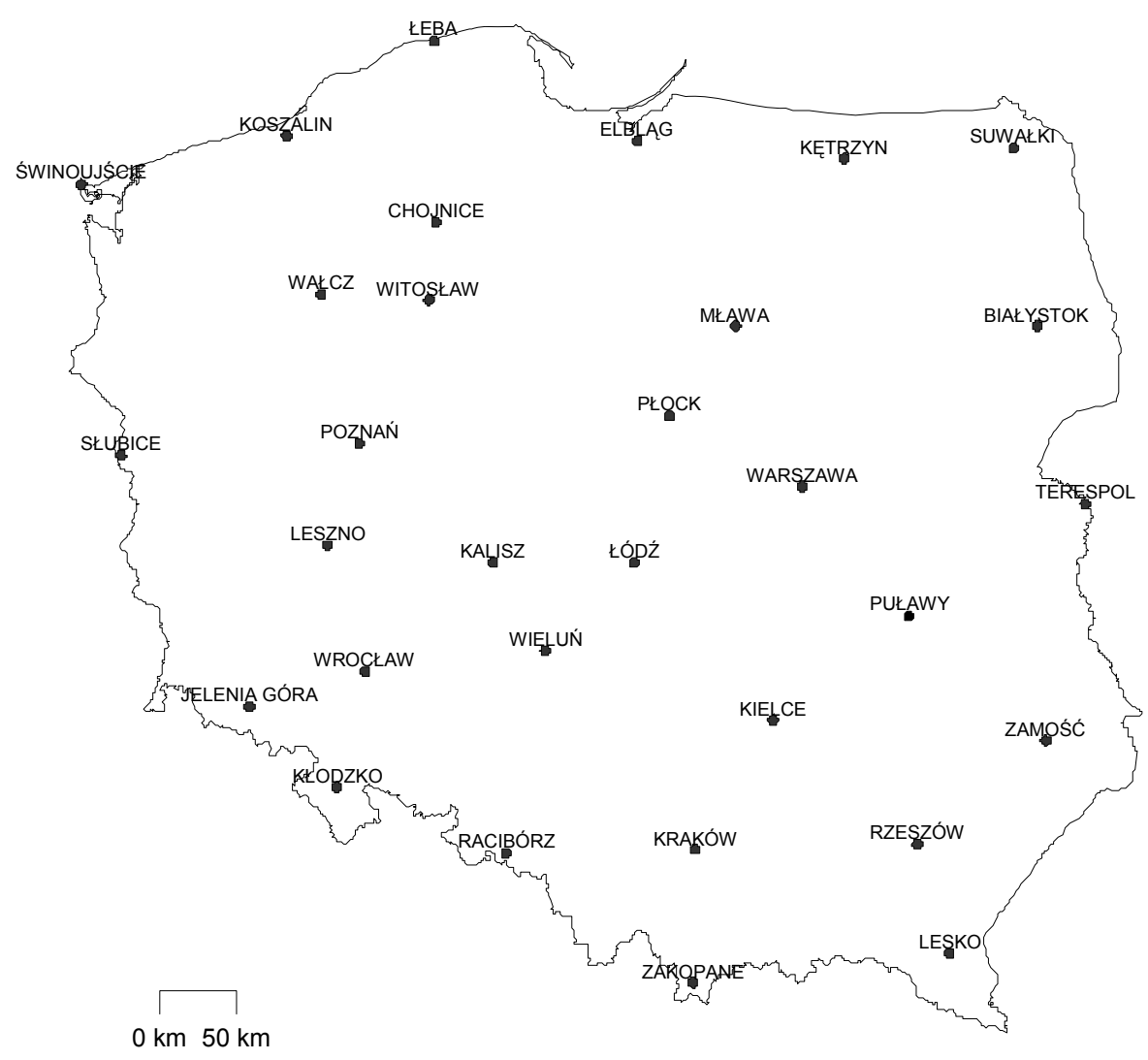

Ryc. 1. Rozmieszczenie stacji meteorologicznych

Fig. 1. Location of meteorological stations

przekształcenie standaryzujące według formuły zastosowanej przez Tamulewicza (1982):

$$
Z_{i j}=\frac{X_{i j}}{\delta}
$$

gdzie:

$Z_{i j} \quad-\quad$ wartość zmiennej standaryzowanej $j$-tej cechy dla $i$-tego

obiektu,

$X_{i j} \quad-\quad$ wartość pierwotna $j$-tej cechy dla $i$-tego obiektu,

$\delta \quad-\quad$ odchylenie standardowe dla całego zbioru danych.

Wartości wyjściowe wyrażone w liczbie odchyleń standardowych utworzyły wtórną macierz porównywalnych zmiennych standaryzowanych. W kolejnym 
kroku przystapiono do oceny podobieństwa i parametryzacji jej przestrzennej zmienności w polu opadów. Oceny tej dokonano przy użyciu współczynnika odległości, w którym stopień podobieństwa wyrażony jest wartością odległości geometrycznej obiektów w badanej przestrzeni wielowymiarowej.

Obliczono odległości między sąsiednimi stacjami połączonymi w sieci grafowej krawędziami. Z powstałego w ten sposób zbioru 20550 odległości wyliczono wartość średniej odległości oraz ich odchylenie standardowe. Zakończenie tego etapu procedury obliczeniowej pozwoliło uzyskać pełną informację o relacjach podobieństwa pomiędzy zestawionymi parami stacji meteorologicznych. Następnie przystąpiono do oceny jakościowej tego podobieństwa, czyli podziału badanych relacji na „podobne” i „odmienne” od siebie. Zazwyczaj przy uwzględniając odległość geometryczną jako miarę wielocechowego podobieństwa, za wartość istotnego podobieństwa przyjmuje się średnią odległość skojarzoną niekiedy z odchyleniem standardowym. Wykonane próby wskazały, że w tym przypadku rolę liczbowego kryterium spełnia wartość średniej odległości geometrycznej, która jest równa 0,94 . W wyniku poczynionych ustaleń za relacje podobieństwa opadowego uznano te krawędzie łączące parę stacji mateorologicznych, dla których obliczona odległość geometryczna jest mniejsza od 0,94 . Stały się one podstawą konstrukcji 274 grafów obrazujących pole podobieństwa opadowego Polski.

\section{ZASTOSOWANIE ELEMENTÓW TEORII GRAFÓW DO BADANIA STRUKTURY POLA OPADÓW}

Badania, których celem jest charakterystyka zależności strukturalnych występujących w przestrzeni, na wstępie wymagają ustalenia optymalnej postaci reprezentacji formalnej danego rodzaju przestrzeni realnej, fizycznej bądź nieposiadającej własności tej ostatniej. Ustalenia, o których tu mowa, komplikuje zwłaszcza wielość struktur formalnych przestrzeni fizycznych i nie fizycznych w sferze nauk społecznych. Szczególnie przydatna dla opisu przestrzeni realnych w sytuacjach dotyczących relacji położenia lub zbiorów przestrzeni realnych jest odwzorowanie struktury przestrzeni za pomocą grafów (Chojnicki 1988).

Teoria grafów jest obszernym i ciagle rozwijającym się działem matematyki dyskretnej. Jej początki związane są z opublikowaniem w 1736 r. pracy L. Eulera, w której za pomocą grafu rozwiązano problem przejścia przez mosty królewieckie na Pregole (Deo 1974; Kulikowski 1986). Samo pojęcie grafu zostało rozpowszechnione dzięki opracowaniu Theorie der endlichen und unendlichen Graphen D. Koniga z 1936 (Marlewski 1989).

Podstawowe pojęcia dotyczące teorii grafów omawiają m.in.: Ford Jr., D.R.F. Fulkerson (1962), Öre (1963), Pulczyn (1968), Alfierova, Ezzeva (1971), 
Szamkołowicz (1971), Deo (1974), Korzan (1978), Ignasiak (1982), Kulikowski (1986), Jankowski (1998), Wilson (2000), Libura, Sikorski (2002), Giaro (2003).

Z przeglądu publikacji, w których korzystano z metod grafowych, wynika, iż terminologia związana $z$ teorią grafów nie ma ściśle ustalonego języka i w wielu przypadkach autorzy używają dowolnie niektórych pojęć. Ta sama definicja może w różnych pracach oznaczać graf: nieskierowany, symetryczny, niezorientowany, prosty lub po prostu graf. Zmiany w sposobie definiowania określonych pojęć wiążą się między innymi z faktem wykorzystywania elementów teorii grafów w coraz to nowych dziedzinach. Niektórzy sądzą, że wszystkie są jednak całkowicie poprawne, pod warunkiem iż używane są konsekwentnie (Wilson 2000; Ciszak, Żurek 1998; Libura, Sikorski 2002). W części metodycznej niniejszej pracy również pojawią się odwołania do elementów teorii grafów. Warto zatem przytoczyć te pojęcia, które w naszym wypadku zostały wykorzystane do analizy strukturalnej pola opadów Polski.

Grafem nazywamy parę uporządkowaną $G=(V, E)$, gdzie $V$ jest zbiorem skończonym, natomiast zbiór $E$ jest rodziną dwuelementowych podzbiorów zbioru $V$. Zbiór $V$ jest nazywany zbiorem wierzchołków grafu $G$, natomiast zbiór $E \subseteq\{\{u, v\}: u, v \in V\}$ nazywany jest zbiorem krawędzi grafu $G$.

Grafem nieskierowanym nazywamy graf, którego krawędzie nie posiadają skierowania (zwrotu).

Graf $G(V, E)$ określamy jako spójny, gdy dla każdej pary jego wierzchołków istnieje łącząca je marszruta.

Graf jest planarny, jeżeli można narysować go na płaszczyźnie z wierzchołkami w różnych punktach i krawędziami w taki sposób, aby żadna para jego krawędzi nie przecinała się.

Grafem prostym nazywamy graf bez krawędzi wielokrotnych i pętli.

Liczbę $n=(V)$ nazywamy rzędem grafu, liczbę $m=(E)$ rozmiarem grafu, a liczbę $g=2 m / n(n-1)$ gęstością grafu.

Jeśli w grafie $G=(V, E)$ istnieje krawędź $e=\{i, j\} \in E$, to mówimy, że wierzchołki $i, j$ są incydentne z krawędzią $e$ albo są końcami krawędzi $e$. Krawędź $e$ jest incydentna $\mathrm{z}$ wierzchołkami $i, j$ lub łączy wierzchołki $i, j$.

Dwa różne wierzchołki, incydentne $\mathrm{z}$ tą samą krawędzią grafu, nazywamy wierzchotkami sqsiednimi lub wierzchotkami zależnymi.

Dwie różne krawędzie grafu, które są incydentne z tym samym wierzchołkiem grafu, nazywamy krawędziami zależnymi.

W grafie $G=(V, E)$ stopniem wierzchołka $i(d(i))$ określamy liczność zbioru $(V(i))$ będącego zbiorem wierzchołków sąsiednich z wierzchołkiem $i V(i)=\{j \in$ $V ;\{i, j\} \in E\}$. Stopień danego wierzchołka jest więc po prostu równy liczbie krawędzi grafu z nim incydentnych.

Wierzchołek, którego stopień jest równy 0 , nazywamy wierzchołkiem izolowanym, natomiast wierzchołek stopnia jeden nazywany jest liściem. Dla 
dowolnego grafu $G$ symbolami $\Delta(g)$ oraz $\delta(G)$ oznacza się odpowiednio największy i najmniejszy ze stopni jego wierzchołków.

W badaniach opartych na elementach teorii grafów istnieje konieczność oceny złożoności struktury pojedynczego grafu lub porównania organizacji przestrzennej dwu lub więcej sieci grafowych. Charakterystykę i różnicowanie grafów przeprowadza się zazwyczaj trzema metodami, poprzez:

- wizualną ocenę sieci,

- konstruowane w tym celu różnorodne miary topologiczne, które charakteryzują właściwości syntetyczne sieci, opisując między innymi jej spójność i dostępność, a także hierarchię węzłów oraz połączeń (Taylor 1980), - metryki określające odległości między grafami.

Zaletą stosowania metod grafowych jest możliwość graficznej prezentacji badanych struktur, a ta $\mathrm{z}$ kolei pozwala na wizualną ocenę złożoności ich organizacji. Uzyskujemy również możliwość wnioskowania o podobieństwie czy niepodobieństwie porównywanych struktur pod względem różnych kryteriów i właściwości genetycznych. Najczęściej stosowane wskaźniki grafowe oparte są na danych odnoszących się do liczby wierzchołków, krawędzi oraz podgrafów i charakteryzują spójność sieci. Powszechnie uznaje się, iż wskaźniki te dobrze opisują strukturalną złożoność zarówno drzew, jak i bardziej rozbudowanych grafów (Palka, Ratajczak, Weltrowska 2001).

Do opisu morfologicznych cech sieci grafowych wykorzystuje się najczęściej trzy wskaźniki charakteryzujące stopień spójności sieci (tab. 3):

1) wskażnik $\gamma$ Kansky'ego, który wyraża stosunek istniejącej liczby krawędzi do maksymalnie możliwej liczby krawędzi,

2) wskaźnik $\eta$ Kansky'ego, który określa relację pomiędzy siecią jako całością a jej krawędziami,

3) stopień rozwinięcia grafu $G$ A. Zagożdżona, który podaje liczbę krawędzi brakujących do grafu pełnego.

Tabela 3. Wskaźniki opisujące stopień spójności sieci grafowych

Table 3. Indicators describing the degree of graph networks consistency

\begin{tabular}{|c|c|c|}
\hline Nazwa & Wskaźnik & Objaśnienia \\
\hline $\begin{array}{l}\text { Wskaźnik } \gamma \text { Kansky'ego } \\
\text { (1963) }\end{array}$ & $\gamma=e / e_{\max }$ & $\begin{array}{c}e-\text { liczba krawędzi istniejących } \\
e_{\max }-\text { maksymalnie możliwa liczba } \\
\text { krawędzi }\end{array}$ \\
\hline $\begin{array}{l}\text { Wskaźnik } \eta \text { Kansky’ego } \\
\text { (1963) }\end{array}$ & $\eta=e+v / e$ & $\begin{array}{l}e \quad-\text { liczba krawędzi } \\
v \quad-\text { liczba wierzchołków }\end{array}$ \\
\hline $\begin{array}{l}\text { Stopień rozwinięcia grafu } \\
\text { wg Zagożdżona } \\
(1977)\end{array}$ & $G=e_{\max }-e / v$ & $\begin{array}{ll}e_{\max }- & \text { maksymalnie możliwa liczba } \\
& \text { krawędzi } \\
e- & \text { liczba krawędzi istniejących } \\
v & - \text { liczba wierzchołków }\end{array}$ \\
\hline
\end{tabular}


W badaniach geograficznych zastosowanie teorii grafów stanowi konsekwentną realizację postulatów analizy systemowej oraz kontynuacji tradycji geografii w zakresie analizy morfometrycznej (Chojnicki 1999). Metody grafowe wykorzystywane są przede wszystkim $w$ badaniach $\mathrm{z}$ dziedziny geografii społeczno-ekonomicznej. Po raz pierwszy pojęcia z teorii grafów zastosowano $\mathrm{w}$ analizie przestrzennej struktury sieci transportowej w opublikowanej w roku 1960 pracy W.L. Garrisona Interstate Highway System. Inne przykłady zastosowań dotyczących badań różnych aspektów struktury sieci transportowej można znaleźć także w publikacjach: Kisslinga (1969), Muraco (1972), Taylora (1975), Ratajczaka (1980). Rozważania z wykorzystaniem pojęć z teorii grafów dotyczące teoretycznych problemów rozwoju sieci transportowej prowadzili między innymi Taaffe, Morril, Gould (1963). W niektórych opracowaniach wykorzystując pewne właściwości grafów, analizuje się problemy dostępności sieci transportowej. Badania takie, dotyczące między innymi sieci kolejowej i autobusowej na obszarze województwa szczecińskiego, przeprowadził Rydzewski (1998, 1999, 2001). Dostępność węzłów i strukturę sieci kolejowej w aglomeracjach miejsko-przemysłowych makroregionu południowego badał Koziarski (1990). Stosunkowo szeroko zagadnienie dostępności w geografii transportu, w tym jej oceny za pomocą metod grafowych omówiła Warakomska (1992). Niektóre własności sieci kolejowej i drogowej Polski za pomoca metod grafowych przedstawił Domański (2000). Pojęcia z teorii grafów do rozwiązania problemu identyfikacji wierzchołków sieci transportowej wykorzystał także Andrzejczak (2003). Natomiast zagadnienie optymalności układów transportowych badał Werner (1969). W geografii osadnictwa niektóre metody grafowe wykorzystał Domański (1970) do przeprowadzenia identyfikacji regionów węzłowych oraz hierarchizacji miast na obszarze okręgu przemysłowego Konin-Łęczyca-Inowrocław. Układ osiedli w postaci grafu przedstawił Zagożdżon (1970), opisując dodatkowo morfologię tego układu za pomocą szeregu wskaźników spójności sieci. Maik (1976) w pracy dotyczącej analizy funkcjonalnej układów osadniczych zastosował niektóre metody dotyczące grafów decyzyjnych. Natomiast w procedurze wyznaczania regionów migracyjnych oraz identyfikacji powiązań migracyjnych niektóre modele grafowe wykorzystała Huk (1991). Interesującą pracę opartą na metodach grafowych opublikowała Weltrowska (2003). Dotyczy ona analizy sieci placówek bankowych na obszarze Polski.

Niektóre elementy teorii grafów okazały się pomocne w badaniach z zakresu geografii fizycznej. Baumgart-Kotarba i Sobański (1978) wykorzystali pojęcia składowej spójności grafu niezorientowanego przy wyznaczaniu grup oraz przy podziale grup na podgrupy w typologii jednostek przestrzennych $w$ randze terenów na arkuszu mapy topograficznej Gorlice.

Zakres tematyczny problematyki niniejszej pracy usytuowany jest na gruncie klimatologii. Wydaje się, że również w tej dyscyplinie przydatne mogą być techniki i metody analityczne związane z teorią grafów. Udaną adaptację metod 
grafowych do badania struktury pola opadów przeprowadził Tamulewicz (1992, 1993). Charakteryzując spójność utworzonych sieci grafowych w celu ustalenia wzajemnych relacji izomorfizmu, rozpatrzono wówczas wskaźniki gamma i eta Kansky'ego oraz stopień względny rozwinięcia grafu Zagożdżona. Podkreślono, iż w badaniach przestrzennych klimatu, a zwłaszcza w badaniach o charakterze relacyjnym ujęcia grafowe niejako w naturalny sposób są preferowane przez wybitnie stacjonarny charakter pomiarów meteorologicznych prowadzonych na ogół w stałych i ściśle zlokalizowanych punktach pola meteorologicznego. Stosowanie metod grafowych wymaga jedynie sprecyzowania założeń dotyczących: wyboru charakteru badanych relacji i ich stosunku do klimatologicznego uogólnienia, sposobu organizacji sieci badania relacji w polu meteorologicznym, przyjęcia metody lub metod testujących i weryfikujących stawiane hipotezy oraz sformułowania zasad wydzielania obszarów o różnym stopniu ciągłości pola.

\section{Konstrukcja sieci grafowej do badania struktury pola opadów}

Zasadniczym i nieodzownym wymogiem grafowej analizy topologicznej jest przedstawienie rzeczywistego obiektu badań jako układu zbioru punktów (wierzchołków) połączonych zbiorem linii (krawędzi). Wymóg ten zostaje spełniony, jeśli poszczególne stacje meteorologiczne potraktujemy jako wierzchołki grafu, które można połączyć krawędziami, tworząc grafową sieć badania struktury pola opadów (Tamulewicz 1993). Należy zaznaczyć, iż utworzona w ten sposób struktura grafowa uwzględnia położenie geograficzne stacji meteorologicznych, stąd można stwierdzić, że mamy do czynienia z grafem geograficznym. Charakter arbitralny posiada natomiast procedura łączenia sąsiednich stacji krawędziami. Sposób przeprowadzenia poszczególnych linii można uznać w pewnym stopniu za dyskusyjny. Właściwa konstrukcja grafowej sieci badania struktury pola opadów Polski została oparta na założeniach przyjętych przez Tamulewicza (1993). Kryteria te zostały wówczas ,pozytywnie” zweryfikowane w odniesieniu do analizy i parametryzacji relacji zachodzących w polu opadów Polski. Na potrzeby niniejszego postępowania badawczego przy tworzeniu sieci grafowej zadbano, aby:

1) sąsiednie stacje zostały połączone krawędziami w taki sposób, że badany obszar został pokryty elementarnymi jednostkami przestrzennymi w kształcie trójkąta,

2) poszczególne trójkąty zostały zbudowane $\mathrm{z}$ możliwie najkrótszych krawędzi, natomiast kąty wewnętrzne trójkątów nie były mniejsze od $30^{\circ}$,

3) utworzona sieć połączeń była grafem planarnym, to znaczy takim, w którym żadne z jego krawędzi nie przecinają się. 
Kryterium trójkątnego kształtu jednostki przestrzennej utworzonej sieci wynika niejako z dyskusji, która zawsze towarzyszy wyborowi optymalnego kształtu podstawowej jednostki badawczej; bardzo często wybór pada właśnie na pole trójkąta. Wymóg kątowy oraz kryterium nie przecinania się krawędzi pozwalają ekstrapolować relacje zachodzące między sąsiednimi wierzchołkami na pewną umowną strefę rozciąnniętą wzdłuż danej krawędzi.

W opracowaniu geograficzny graf badania struktury pola opadów Polski ma 31 wierzchołków (rząd grafu $n=31$ ), między którymi rozpięto 75 krawędzi (rozmiar grafu $m=75$ ) (ryc. 2). Gęstość grafu wynosi $g=0,16$. Jest on grafem: częściowym, planarnym, płaskim, nieskierowanym, spójnym. W powstałej sieci brak jest wierzchołków izolowanych i liści. Największy stopień wierzchołka wynosi $\Delta(15)=7$, najmniejszy zaś $\delta(5)=2$.

Wybrane wskaźniki charakteryzujące stopień spójności sieci dla grafu całkowicie spójnego przyjmują wartości: $\gamma=1, \eta=1,41, G=0$.

Krawędzie, które rozpięto w powstałym grafie pomiędzy sąsiednimi stacjami charakteryzują się różnymi długościami pozostającymi w stosunku odpowiedniości do rzeczywistych odległości między nimi. Najbardziej oddalone od siebie stacje Płock-Poznań dzieli nieco ponad $195 \mathrm{~km}$. Natomiast najkrótsza odległość (50,3 km) łączy stacje Chojnice i Witosław (tab. 4).

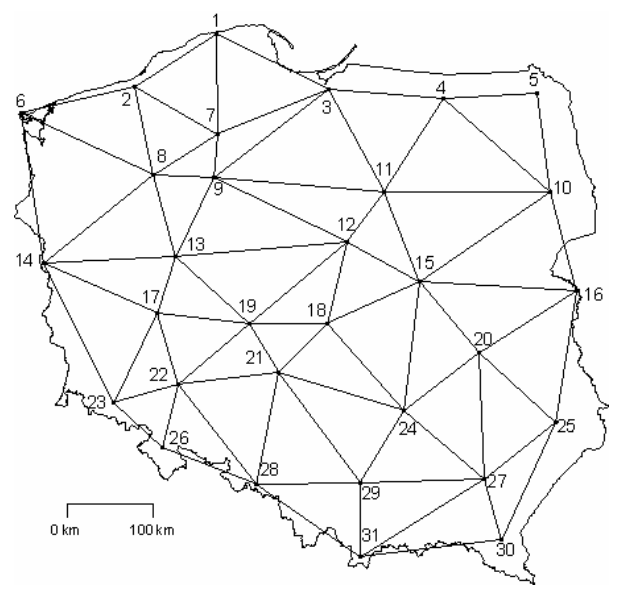

Ryc. 2. Geograficzny graf badania struktury pola opadów

Fig. 2. Geographical graph showing precipitation area structure 
Tabela 4. Krawędzie geograficznego grafu badania struktury pola opadów według długości

Table 4. Edges of the geographical graph representing precipitation area structure by length

\begin{tabular}{|c|c|c|}
\hline Lp. & Krawędź & Długość [km] \\
\hline 1 & Łeba-Koszalin & 108,2 \\
\hline 2 & Łeba-Elblag & 138,9 \\
\hline 3 & Łeba-Chojnice & 116,9 \\
\hline 4 & Koszalin-Świnoujście & 129,3 \\
\hline 5 & Koszalin-Chojnice & 107,3 \\
\hline 6 & Koszalin-Wałcz & 104,6 \\
\hline 7 & Elblag-Kętrzyn & 127,1 \\
\hline 8 & Elblag-Chojnice & 133,9 \\
\hline 9 & Elblag-Witosław & 164,3 \\
\hline 10 & Elblag-Mława & 133,7 \\
\hline 11 & Kętrzyn-Suwałki & 103,4 \\
\hline 12 & Kętrzyn-Białystok & 160,7 \\
\hline 13 & Kętrzyn-Mława & 127,3 \\
\hline 14 & Suwałki-Białystok & 115,6 \\
\hline 15 & Świnoujście-Wałcz & 164,2 \\
\hline 16 & Świnoujście-Słubice & 176,5 \\
\hline 17 & Chojnice-Wałcz & 85,5 \\
\hline 18 & Chojnice-Witosław & 50,3 \\
\hline 19 & Wałcz-Witosław & 67,3 \\
\hline 20 & Wałcz-Poznań & 98,8 \\
\hline 21 & Wałcz-Słubice & 162,9 \\
\hline 22 & Witosław-Mława & 192,2 \\
\hline 23 & Witosław-Płock & 168,4 \\
\hline 24 & Witosław-Poznań & 102,2 \\
\hline 25 & Białystok-Mława & 188,5 \\
\hline 26 & Białystok-Warszawa & 181,1 \\
\hline 27 & Białystok-Terespol & 118,6 \\
\hline 28 & Mława-Płock & 71,3 \\
\hline 29 & Mława-Warszawa & 111,7 \\
\hline 30 & Płock-Poznań & 197,3 \\
\hline 31 & Płock-Warszawa & 95,8 \\
\hline 32 & Płock-Łódź & 97,3 \\
\hline 33 & Płock-Kalisz & 147,2 \\
\hline 34 & Poznań-Słubice & 151,7 \\
\hline 35 & Poznań-Leszno & 68,8 \\
\hline 36 & Poznań-Kalisz & 115,0 \\
\hline
\end{tabular}




\begin{tabular}{|c|c|c|}
\hline Lp. & Krawędź & Długość [km] \\
\hline 37 & Słubice-Leszno & 144,1 \\
\hline 38 & Słubice-Jelenia Góra & 181,5 \\
\hline 39 & Warszawa-Terespol & 181,5 \\
\hline 40 & Warszawa-Łódź & 118,3 \\
\hline 41 & Warszawa-Puławy & 108,2 \\
\hline 42 & Warszawa-Kielce & 151,5 \\
\hline 43 & Terespol-Puławy & 134,8 \\
\hline 44 & Terespol-Zamość & 154,7 \\
\hline 45 & Leszno-Kalisz & 107,3 \\
\hline 46 & Leszno-Wrocław & 84,8 \\
\hline 47 & Leszno-Jelenia Góra & 115,3 \\
\hline 48 & Łódź-Kalisz & 91,0 \\
\hline 49 & Łódź-Wieluń & 80,8 \\
\hline 50 & Łódź-Kielce & 135,9 \\
\hline 51 & Kalisz-Wieluń & 66,2 \\
\hline 52 & Kalisz-Wrocław & 108,9 \\
\hline 53 & Puławy-Kielce & 111,1 \\
\hline 54 & Puławy-Zamość & 120,2 \\
\hline 55 & Puławy-Rzeszów & 147,1 \\
\hline 56 & Wieluń-Wrocław & 118,7 \\
\hline 57 & Wieluń-Kielce & 155,7 \\
\hline 58 & Wieluń-Racibórz & 132,8 \\
\hline 59 & Wieluń-Kraków & 161,7 \\
\hline 60 & Wrocław-Jelenia Góra & 78,9 \\
\hline 61 & Wrocław-Kłodzko & 76,8 \\
\hline 62 & Wrocław-Racibórz & 149,6 \\
\hline 63 & Jelenia Góra-Kłodzko & 78,0 \\
\hline 64 & Kielce-Rzeszów & 124,8 \\
\hline 65 & Kielce-Kraków & 98,2 \\
\hline 66 & Zamość-Rzeszów & 108,2 \\
\hline 67 & Zamość-Lesko & 151,3 \\
\hline 68 & Kłodzko-Racibórz & 120,2 \\
\hline 69 & Rzeszów-Kraków & 148,6 \\
\hline 70 & Rzeszów-Lesko & 73,4 \\
\hline 71 & Rzeszów-Zakopane & 175,5 \\
\hline 72 & Racibórz-Kraków & 126,5 \\
\hline 73 & Racibórz-Zakopane & 151,2 \\
\hline 74 & Kraków-Zakopane & 85,7 \\
\hline 75 & Lesko-Zakopane & 174,9 \\
\hline
\end{tabular}




\section{STRUKTURALNE CECHY POLA OPADÓW POLSKI W ZALEŻNOŚCI OD CHARAKTERU CYRKULACJI}

Analityczna część pracy w warstwie rachunkowej podporządkowana została przyjętej koncepcji metodycznej, zgodnie z którą zasadniczym celem postępowania badawczego będzie geograficzna identyfikacja przypadków ciągłości przestrzennej w polu opadów Polski. Oznacza to w praktyce, że zadaniem przyjętego algorytmu będzie zlokalizowanie w obrębie sieci grafowej sytuacji, kiedy między sąsiednimi stacjami meteorologicznymi (węzłami sieci), czyli wzdłuż krawędzi grafu zachodzi relacja podobieństwa stosunków opadowych. Punktem wyjścia dokonanych obliczeń był zbiór 274 sieci grafowych liczebnie tożsamych z ilością wszystkich (w latach 1951-1990) ciagów co najmniej 7 kolejnych dni, w których stwierdzono (na podstawie kalendarza typów cyrkulacji wg Lityńskiego) taki sam typ cyrkulacji. W każdej sieci grafowej pozostawiono jedynie te krawędzie, które łączą tylko te sąsiednie stacje, które w świetle przyjętych kryteriów spełniają w danym ciagu dni z określonym typem cyrkulacji wymóg podobieństwa (jednorodności) reżimu opadów. Otrzymano zatem w każdym przypadku graf złożony z ,krawędzi podobieństwa”. Umownie można przyjąć, że zostały w ten sposób uzyskane geometryczne obrazy relacji pluwiometrycznego podobieństwa w polu opadów Polski. Biorąc pod uwagę liczbę krawędzi łączących stacje podobne pod względem reżimu opadów, można za pomocą wskaźników spójności sieci grafowych wzajemnie porównywać spójność otrzymanych struktur (grafów) podobieństwa. Wykorzystano trzy wskaźniki: gamma Kansky’ego, eta Kansky’ego i rozwinięcia grafu Zagożdżona. Wszystkie uwzględniają topologiczne własności sieci. Dla grafu całkowicie spójnego wskaźniki charakteryzujące stopień spójności sieci przyjmują wartości: $\gamma=1, \eta=1,41, G=0$. W celu wyraźniejszego zróżnicowania charakteru spójności otrzymanych struktur grafowych, opierając się na wartościach powyższych wskaźników, wydzielono trzy kategorie spójności sieci (tab. 5).

Tabela 5. Kategorie spójności sieci grafowych

Table 5. Categories of graph networks consistency

\begin{tabular}{lccc}
\hline \multicolumn{1}{c}{$\begin{array}{c}\text { Kategorie spójności } \\
\text { sieci grafowych }\end{array}$} & $\gamma$ & $\eta$ & Wskaźniki spójności \\
\cline { 2 - 4 } & $0,01-0,33$ & $2,24-32,00$ & $1,61-2,39$ \\
\hline Mała & & & \\
[przedział I] & Średnia \\
[przedział II] & $0,35-0,67$ & $1,62-2,19$ & $0,80-1,58$ \\
$\begin{array}{l}\text { Duża } \\
\text { [przedział III] }\end{array}$ & $1,68-1,00$ & $1,41-1,61$ & $0,00-0,77$ \\
\hline
\end{tabular}


Jako mało spójne określono grafy, dla których wartość wskaźnika $\gamma$ wynosi od 0,01 do 0,33 , wartość wskaźnika $\eta$ zawiera się w przedziale od 2,24 do 32,0 a wskaźnik $G$ przyjmuje wartości od 1,61 do 2,39. Przypadki obrazów grafowych dla których wartości poszczególnych wskaźników mieszczą się w przedziałach; $\gamma$ od 0,35 do 0,$67 ; \eta$ od 1,62 do 2,$19 ; G$ od 0,8 do 1,58 , uznano za średnio spójne. Natomiast jeśli wartość wskaźnika gamma Kansky'ego wynosi od 0,68 do 1,0, wartość wskaźnika eta od 1,41 do 1,61, a wartość wskaźnika rozwinięcia grafu Zagożdżona od 0 do 0,77 , to sieci takie określono jako grafy o dużej spójności.

Podstawą postępowania badawczego zmierzającego $\mathrm{w}$ niniejszym opracowaniu do udzielenia odpowiedzi na pytanie, czy i w jakim zakresie przestrzenne związki pluwiometrycznego podobieństwa pozostają pod wpływem czynników cyrkulacyjnych, jest analiza zbioru wszystkich sieci grafowych.

W części analitycznej postępowania badawczego dokonano oceny poszczególnych relacji pod względem częstości, z jaką wzdłuż wyznaczonych krawędzi zachodzą relacje wzajemnego podobieństwa pluwiometrycznego. Przeprowadzone obliczenia miały za zadanie ustalenie dla każdej z 75 krawędzi sieci faktycznej liczby przypadków (na 274 możliwych), kiedy dana krawędź była krawędzią podobieństwa. Możliwych opcji analitycznych jest w tym przypadku kilka. Mianowicie, w zbiorze 274 sieci można wyodrębnić podzbiory składające się z ciągów dni jednorodnych ze względu na charakter cyrkulacji atmosferycznej (cyklonalna, pośrednia i antycyklonalna) z pominięciem kierunku przenosu mas powietrznych lub odwrotnie, uwzględniające na przykład kierunek napływu tych mas z pominięciem charakteru cyrkulacji. Wspomniana segregacja może w każdym przypadku dodatkowo uwzględniać na przykład sezonowość występowania poszczególnych ciągów dni (sieci grafowych) i zostać przeprowadzona oddzielnie dla półrocza ciepłego i chłodnego. Jest oczywiste, że wówczas ustalenie konkretnych wartości częstości „krawędzi podobieństwa" każdorazowo uwzględnia inną (mniejszą niż 274) liczbę sieci tworzących poszczególne podzbiory. Przyjęta procedura pozwoliła na utworzenie grafów tylko z tych relacji sieci, wzdłuż których pozytywne relacje podobieństwa opadowego zachodziły z częstością kolejno: $>10 \%,>20 \%,>30,>40 \%$, $>50 \%,>60 \%,>70 \%,>80 \%$ i $>90 \%$. Uzyskano w ten sposób sekwencje obrazów grafowych przedstawiających graficznie strukturę pola opadów na wyznaczonych poziomach częstości podobieństwa opadowego z jednoczesną oceną charakteru ich spójności.

\section{Ocena spójności grafowych sieci podobieństwa opadowego}

Otrzymany zbiór 274 obrazów grafowych jest silnie zróżnicowany pod względem liczby krawędzi budujących daną sieć. Liczba relacji podobieństwa 
opadowego w utworzonych sieciach grafowych waha się od 9 do 75, a maksymalna wartość tego zakresu jest charakterystyczna dla sytuacji, w których skonstruowane sieci są odwzorowaniem grafu wyjściowego (ryc. 3).

Rozkład liczby obrazów grafowych w wyróżnionych przedziałach spójności, w różnych kategoriach cyrkulacji, przedstawiono w tabeli 6a. Analiza powyższego zestawienia pozwala stwierdzić, iż w przypadku cyrkulacji cyklonalnej i pośredniej najbardziej liczną grupę utworzyły sieci o średnim stopniu spójności (przedział II). W przypadku cyrkulacji cyklonalnej stanowiły one $60 \%$ wszystkich zdarzeń, a przy cyrkulacji pośredniej $62,2 \%$. Mniej liczne były grafy o dużej spójności. Odnotowano odpowiednio $23,3 \%$ tego typu przypadków w warunkach cyrkulacji cyklonalnej i 29,7\% przy cyrkulacji pośredniej. Zdecydowanie najmniej liczebną grupą są sieci o małej spójności. W warunkach cyrkulacji cyklonalnej stanowiły one $16,7 \%$, a przy cyrkulacji pośredniej zaledwie $8,1 \%$ zdarzeń. Odmienny rozkład liczby zdarzeń mieszczących się w poszczególnych przedziałach spójności charakteryzuje rozpatrywane ciagi dni z cyrkulacją antycyklonalną. W tym przypadku przegląd wartości wyliczonych wskaźników spójności sieci podobieństwa wskazuje, że 63,9\% analizowanych grafów charakteryzuje się dużą spójnością. Ponad $28 \%$ sieci znalazło się w przedziale drugim spójności i jedynie 7,5\% sieci określono jako grafy o mały stopniu spójności.

W ujęciu sezonowym należy zwrócić uwagę na fakt, iż w półroczu ciepłym we wszystkich kategoriach cyrkulacji przeważają sieci o średniej spójności (tab. 6b). W warunkach cyrkulacji pośredniej ich udział jest największy i wynosi $65 \%$, przy cyrkulacji cyklonalnej równy jest $57,5 \%$, a przy cyrkulacji antycyklonalnej osiagnął 44,3\%. Najmniej liczne w sytuacji cyrkulacji cyklonalnej okazały się sieci o dużej spójności (przedział III), a w warunkach cyrkulacji pośredniej i antycyklonalnej grafy o małym stopniu spójności (przedział I).

W chłodnym okresie roku, w sytuacji cyrkulacji cyklonalnej i pośredniej, przeważają sieci o średnim stopniu spójności, które stanowiły odpowiednio $62 \%$ i 58,8\% zdarzeń (tab. 6c). W warunkach cyrkulacji antycyklonalnej zdecydowanie dominują grafy o dużej spójności. Spośród 77 rozpatrywanych w tym przypadku zdarzeń w najwyższym przedziale spójności odnotowano aż 66 grafów $(85,7 \%)$. Należy podkreślić, że w półroczu chłodnym zarówno w warunkach cyrkulacji cyklonalnej, pośredniej jak, i antycyklonalnej nie odnotowano przypadku sieci o małej spójności (przedział I). 


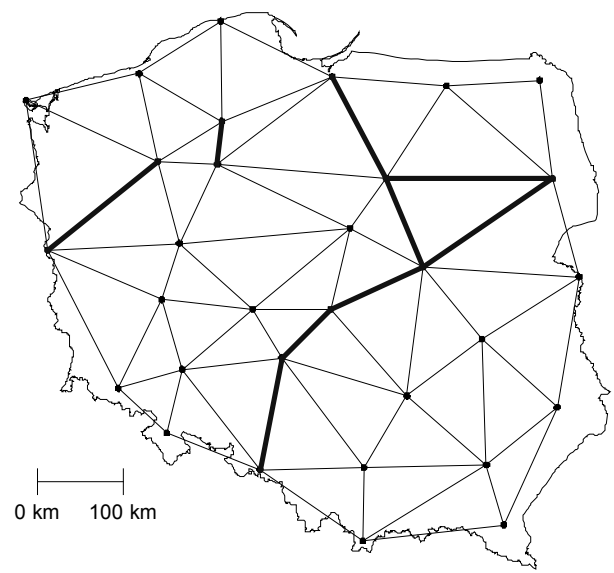

$\mathrm{Nc}$

27.06.-03.07.1959 r.

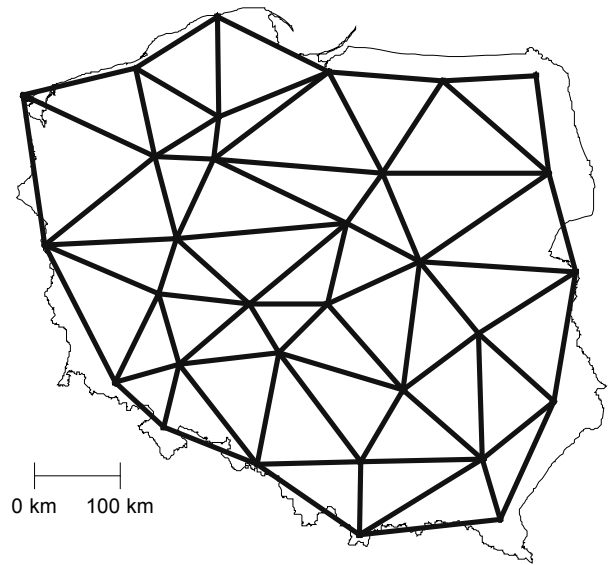

$\mathrm{SEa}$

27.02-06.03.1974 r.

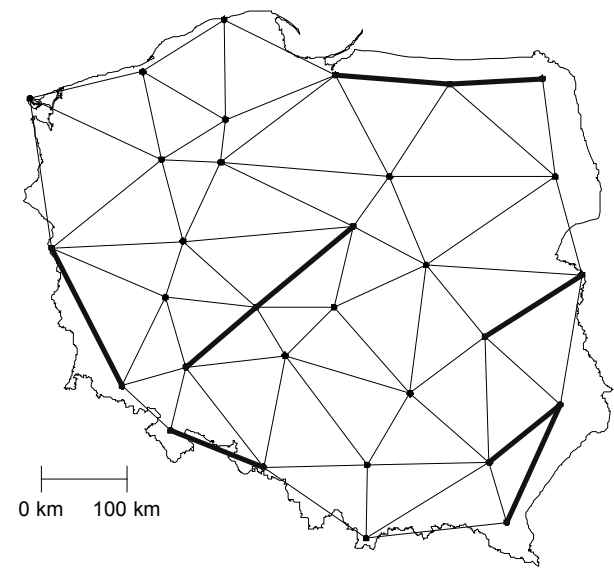

SEc

13-25.06.1969 r.

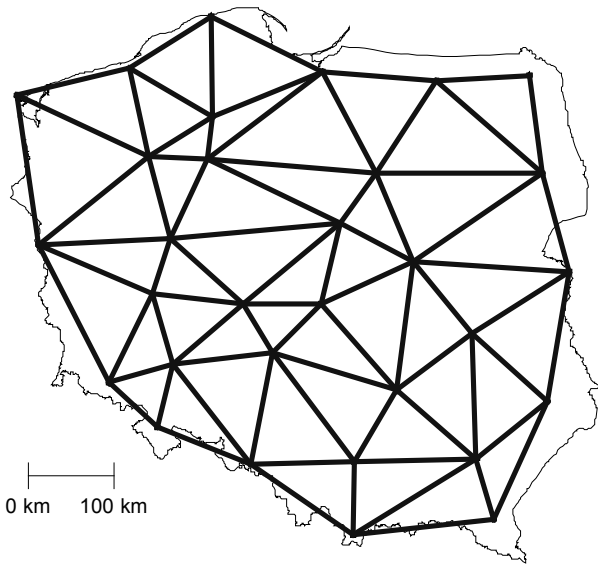

$\mathrm{Oa}$

13-21.01.1982 r.

Ryc. 3. Krawędzie podobieństwa opadowego. Przykłady struktur najmniej i najbardziej spójnych

Fig. 3. Precipitation similarity edges. Examples of the least and most consistent structures 
Tabela 6. Liczba sieci o różnej kategorii spójności w warunkach cyrkulacji cyklonalnej, pośredniej i antycyklonalnej - rok (a), półrocze ciepłe (b), półrocze chłodne (c)

Table 6. Number of networks of different consistency categories under cyclonic, intermediate and anti-cyclonic circulation - year (a), warm half-year (b), cold half-year (c)

a

\begin{tabular}{|c|c|c|c|c|c|c|c|c|}
\hline \multirow{3}{*}{$\begin{array}{l}\text { Charakter } \\
\text { cyrkulacji }\end{array}$} & \multicolumn{8}{|c|}{$\begin{array}{c}\text { Sieci grafowe według kategorii spójności } \\
- \text { rok }\end{array}$} \\
\hline & \multicolumn{2}{|c|}{$\begin{array}{c}\text { mała } \\
\text { [przedział I] }\end{array}$} & \multicolumn{2}{|c|}{$\begin{array}{c}\text { średnia } \\
\text { [przedział II] }\end{array}$} & \multicolumn{2}{|c|}{$\begin{array}{c}\text { duża } \\
\text { [przedział III] }\end{array}$} & \multicolumn{2}{|c|}{ razem } \\
\hline & liczba & $\begin{array}{l}\text { udział } \\
{[\%]}\end{array}$ & liczba & $\begin{array}{l}\text { udział } \\
{[\%]}\end{array}$ & liczba & $\begin{array}{l}\text { udział } \\
{[\%]}\end{array}$ & liczba & $\begin{array}{c}\text { udział } \\
{[\%]}\end{array}$ \\
\hline Cyklonalna & 15 & 16,7 & 54 & 60,0 & 21 & 23,3 & 90 & 100,0 \\
\hline Pośrednia & 3 & 8,1 & 23 & 62,2 & 11 & 29,7 & 37 & 100,0 \\
\hline Antycyklonalna & 11 & 7,5 & 42 & 28,6 & 94 & 63,9 & 147 & 100,0 \\
\hline
\end{tabular}

b

\begin{tabular}{|c|c|c|c|c|c|c|c|c|}
\hline \multirow{3}{*}{$\begin{array}{l}\text { Charakter } \\
\text { cyrkulacji }\end{array}$} & \multicolumn{8}{|c|}{$\begin{array}{l}\text { Sieci grafowe według kategorii spójności } \\
\text { - półrocze ciepłe [V-X] }\end{array}$} \\
\hline & \multicolumn{2}{|c|}{$\begin{array}{c}\text { mała } \\
\text { [przedział I] }\end{array}$} & \multicolumn{2}{|c|}{$\begin{array}{c}\text { średnia } \\
\text { [przedział II] }\end{array}$} & \multicolumn{2}{|c|}{$\begin{array}{c}\text { duża } \\
\text { [przedział III] }\end{array}$} & \multicolumn{2}{|c|}{ razem } \\
\hline & liczba & $\begin{array}{c}\text { udział } \\
{[\%]}\end{array}$ & liczba & $\begin{array}{c}\text { udział } \\
{[\%]}\end{array}$ & liczba & $\begin{array}{c}\text { udział } \\
{[\%]}\end{array}$ & liczba & $\begin{array}{c}\text { udział } \\
\text { [\%] }\end{array}$ \\
\hline Cyklonalna & 15 & 37,5 & 23 & 57,5 & 2 & 5,0 & 40 & 100,0 \\
\hline Pośrednia & 3 & 15,0 & 13 & 65,0 & 4 & 20,0 & 20 & 100,0 \\
\hline Antycyklonalna & 11 & 15,7 & 31 & 44,3 & 28 & 40,0 & 70 & 100,0 \\
\hline
\end{tabular}

C

\begin{tabular}{|c|c|c|c|c|c|c|c|c|}
\hline \multirow{3}{*}{$\begin{array}{l}\text { Charakter } \\
\text { cyrkulacji }\end{array}$} & \multicolumn{8}{|c|}{$\begin{array}{l}\text { Sieci grafowe według kategorii spójności } \\
\text { - półrocze chłodne [XI-IV] }\end{array}$} \\
\hline & \multicolumn{2}{|c|}{$\begin{array}{c}\text { mała } \\
\text { [przedział I] }\end{array}$} & \multicolumn{2}{|c|}{$\begin{array}{c}\text { średnia } \\
\text { [przedział II] }\end{array}$} & \multicolumn{2}{|c|}{$\begin{array}{c}\text { duża } \\
\text { [przedział III] }\end{array}$} & \multicolumn{2}{|c|}{ razem } \\
\hline & liczba & $\begin{array}{c}\text { udział } \\
{[\%]}\end{array}$ & liczba & $\begin{array}{l}\text { udział } \\
{[\%]}\end{array}$ & liczba & $\begin{array}{l}\text { udział } \\
{[\%]}\end{array}$ & liczba & $\begin{array}{c}\text { udział } \\
{[\%]}\end{array}$ \\
\hline Cyklonalna & 0 & 0,0 & 31 & 62,0 & 19 & 38,0 & 50 & 100,0 \\
\hline Pośrednia & 0 & 0,0 & 10 & 58,8 & 7 & 41,2 & 17 & 100,0 \\
\hline Antycyklonalna & 0 & 0,0 & 11 & 14,3 & 66 & 85,7 & 77 & 100,0 \\
\hline
\end{tabular}




\section{Częstość pojawiania się relacji pluwiometrycznego podobieństwa w polu opadów Polski w zależności od charakteru cyrkulacji}

\section{Relacje podobieństwa w sytuacjach o charakterze cyklonalnym}

\section{Rok}

W badanym wieloleciu 1951-1990 wydzielono ogółem 90 ciągów dni co najmniej 7-dniowych z cyrkulacją o charakterze cyklonalnym. Analizie poddano częstość występowania cech podobieństwa reżimu opadowego wzdłuż wyznaczonych krawędzi we wszystkich wyróżnionych sekwencjach dni tego typu. Średnia częstość pojawiania się w polu opadów relacji podobieństwa opadowego wyniosła w tym przypadku 52,2\%. Z najmniejszą częstością $(24,4 \%)$ te same cechy reżimu pluwiometrycznego odnotowywano wzdłuż krawędzi przecinającej Beskidy Zachodnie, a łączącej miejscowości Racibórz i Zakopane. Z kolei najwyższym podobieństwem stosunków opadowych - wynoszącym 71,1\% - wyróżniła się relacja Zamość-Rzeszów. Liczba relacji podobnych w dwóch najniższych rozpatrywanych przedziałach częstości $(>10 \%,>20 \%)$ wyniosła 75. Skonstruowane dla tych zakresów częstości sieci grafowe są grafami spójnymi, a opisujące je wskaźniki stopnia spójności przyjęły wartości maksymalne (tab. 7). Z częstością większą od 30\% zidentyfikowano w polu opadów 73 relacje podobne. Dwa kontrasty niepodobieństwa opadowego położone są na przeciwstawnych krańcach Polski. Pierwszy, zlokalizowany w północnej Polsce, poprowadzony jest wzdłuż Pobrzeża Gdańskiego i łączy stacje Łeba-Elbląg. Drugi, jak

Tabela 7. Spójność grafów o różnej częstości podobieństwa opadowego w warunkach cyrkulacji cyklonalnej

Table 7. Consistency of graphs showing different frequency of precipitation similarity under cyclonic circulation

\begin{tabular}{|c|c|c|c|c|c|c|c|c|c|}
\hline \multirow{3}{*}{$\begin{array}{c}\text { Częstość } \\
\text { podobieństwa } \\
{[\%]}\end{array}$} & \multicolumn{3}{|c|}{$\begin{array}{l}\text { Półrocze ciepłe } \\
{[\mathrm{V}-\mathrm{X}]}\end{array}$} & \multirow{2}{*}{\multicolumn{3}{|c|}{$\begin{array}{l}\text { Półrocze chłodne } \\
{[\mathrm{XI}-\mathrm{IV}]}\end{array}$}} & \multicolumn{3}{|c|}{ Rok } \\
\hline & \multirow[b]{2}{*}{$\gamma$} & \multirow[b]{2}{*}{$\eta$} & \multirow[b]{2}{*}{$G$} & & & & & & \\
\hline & & & & $\gamma$ & $\eta$ & $G$ & $\gamma$ & $\eta$ & $G$ \\
\hline$>10$ & 1 & 1,41 & 0 & 1 & 1,41 & 0 & 1 & 1,41 & 0 \\
\hline$>20$ & 0,96 & 1,43 & 0,1 & 1 & 1,41 & 0 & 1 & 1,41 & 0 \\
\hline$>30$ & 0,77 & 1,53 & 0,55 & 1 & 1,41 & 0 & 0,97 & 1,42 & 0,06 \\
\hline$>40$ & 0,4 & 2,03 & 1,45 & 0,96 & 1,43 & 0,1 & 0,93 & 1,44 & 0,16 \\
\hline$>50$ & 0,12 & 4,44 & 2,13 & 0,87 & 1,48 & 0,32 & 0,6 & 1,69 & 0,97 \\
\hline$>60$ & 0,01 & 32,0 & 2,39 & 0,63 & 1,66 & 0,9 & 0,23 & 2,82 & 1,87 \\
\hline$>70$ & & & & 0,2 & 3,07 & 1,94 & 0,01 & 32,0 & 2,39 \\
\hline$>80$ & & & & 0,03 & 16,5 & 2,35 & & & \\
\hline$>90$ & & & & & & & & & \\
\hline
\end{tabular}


już wspomniano, znajduje się w obrębie Karpat (Racibórz-Zakopane) (ryc. 4). Na kolejnym, wyższym poziomie częstości (> 40\%) odnotowano 70 krawędzi podobnych. Na większości obszaru Polski tworzą one zwartą strukturę poprzerywaną występowaniem relacji niepodobieństwa opadowego jedynie na terenie wschodniej części Pojezierza Pomorskiego, Pogórza Karpackiego i Karpat oraz w zachodniej części Niziny Śląskiej (ryc. 4). Wartości wskaźników spójności sieci grafowych utworzonych dla przedziałów częstości $>30 \%$ i $>40 \%$ są do siebie zbliżone (tab. 7). Grafy te charakteryzują się dużą spójnością. Przejście do kolejnego wyższego zakresu częstości podobieństwa opadowego (> 50\%) powoduje spadek liczby krawędzi podobnych. W przedziale tym znalazło się 45 krawędzi. W utworzonym grafie zwraca uwagę wyraźnie zaznaczona północna granica występowania w polu opadowym relacji podobieństwa pluwiometrycznego, która przebiega wzdłuż trasy Słubice-Wałcz-Chojnice-Elbląg (ryc. 4). Spójność tego grafu opisują następujące wskaźniki: $\gamma=0,6, \eta=1,69, G=0,97$. Z kolei z częstością większą od $60 \%$ zlokalizowano w polu opadowym 17 relacji podobnych skupionych $w$ trzech podgrafach. Pierwszy z nich położony jest w obrębie Pojezierza Pomorskiego i składa się z dwóch krawędzi incydentnych: Chojnice-Wałcz i Chojnice-Witosław. Drugi obejmuje tylko jedną parę stacji położonych na Wyżynie Lubelskiej (Zamość-Rzeszów). Natomiast trzeci stanowi rozbudowaną strukturę składającą się z 14 krawędzi położonych głównie w obrębie Pojezierza Wielkopolskiego i Niziny Śląskiej (ryc. 4). Wskaźnik gamma Kansky'ego dla tej sieci wynosi 0,23, wskaźnik eta Kansky'go równy jest 2,82 , a wskaźnik rozwinięcia grafu Zagożdżona wynosi 1,87. Spośród wszystkich testowanych kontrastów tylko dla jednej pary stacji częstość podobieństwa opadowego wzdłuż badanej relacji przekroczyła 70\%. Dotyczy to krawędzi łączącej stacje Zamość i Rzeszów (ryc. 4). Spójność ostatniego grafu z tej serii ujęć graficznych wyniosła odpowiednio: $\gamma=0,01, \eta=32,0, G=2,39$.

\section{Półrocze ciepłe}

Półrocze ciepłe jest okresem o mniejszej częstości pojawiania się relacji podobnych w polu opadowym. Obliczona dla tego okresu roku średnia jest niższa od $40 \%$ i wynosi zaledwie $39,1 \%$. Jedynie w najniższym przedziale częstości (> 10\%) odnotowano 75 relacji podobnych, stąd w wykonanej sekwencji ujęć grafowych otrzymano tylko jeden graf spójny (tab. 7). Z częstością większą od $20 \%$ odnotowano w polu opadów 72 krawędzie podobieństwa (ryc. 5). Wzdłuż trzech brakujących krawędzi położonych między innymi w obrębie Pogórza Karpackiego i Karpat (Racibórz-Zakopane, Racibórz-Kraków) oraz w środkowej części Pojezierza Pomorskiego (Koszalin-Chojnice) podobne cechy reżimu opadowego występowały z częstością mniejszą od 20\%. Minimalną częstość stwierdzono wzdłuż krawędzi Racibórz-Zakopane i wyniosła ona 12,5\%, co oznacza, że jedynie w pięciu przypadkach na 40 rozpatrywanych między tą parą stacji zachodziło podobieństwo opadowe. $Z$ częstością $>30 \%$ pojawiło 

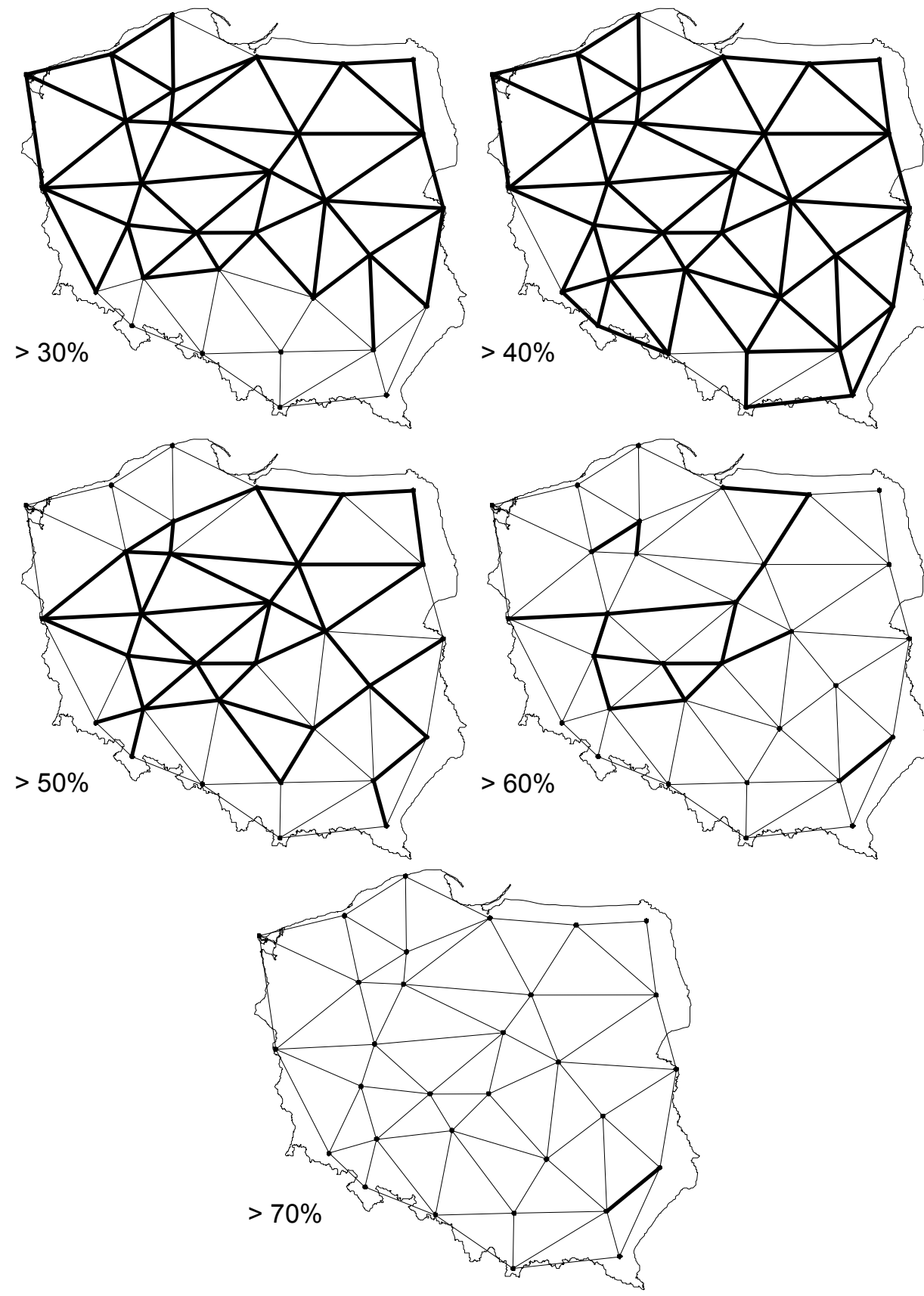

Ryc. 4. Krawędzie o różnej częstości podobieństwa opadowego w warunkach cyrkulacji cyklonalnej - rok

Fig. 4. Edges showing different frequency of precipitation similarity under cyclonic circulation - year 

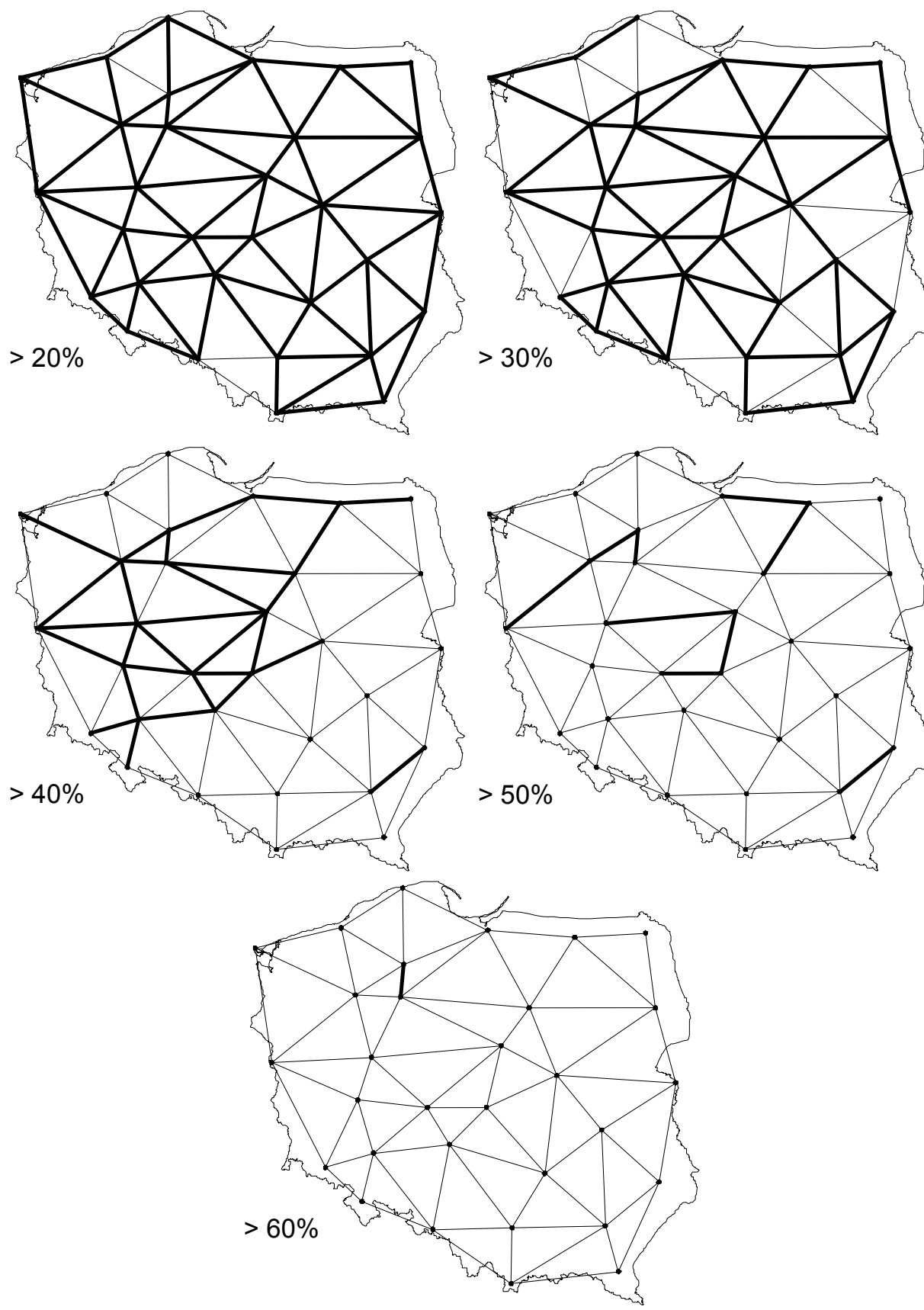

Ryc. 5. Krawędzie o różnej częstości podobieństwa opadowego w warunkach cyrkulacji cyklonalnej - półrocze ciepłe

Fig. 5. Edges showing different frequency of precipitation similarity under cyclonic circulation warm half-year 
się w polu opadowym 58 relacji podobnych zlokalizowanych głównie: w południowej części Pojezierza Pomorskiego, na Pojezierzu Mazurskim, na Pojezierzu i Nizinie Wielkopolskiej, Nizinie Śląskiej, w Sudetach i na Wyżynie Małopolskiej. W północnej Polsce podobieństwo opadowe stwierdzono jedynie wzdłuż relacji poprowadzonych równolegle do Pobrzeża Szczecińskiego i Koszalińskiego (Świnoujście-Koszalin i Koszalin-Łeba) oraz wzdłuż krawędzi Świnoujście-Wałcz (ryc. 5). Wskaźnik gamma Kansky’ego dla tej sieci wyniósł 0,77 , wskaźnik eta Kansky'ego równy jest 1,53, a wskaźnik Zagożdżona przyjął wartość 0,55 . W grafie obrazującym strukturę pola opadów półrocza ciepłego utworzonym przez relacje podobieństwa opadowego, występujące z częstością większą od $40 \%$, znalazło się 30 krawędzi. W układzie przestrzennym zwraca uwagę ich koncentracja na obszarze Pojezierza i Niziny Wielkopolskiej (ryc. 5). Spójność tej sieci jest mniejsza od poprzedniego grafu i wynosi odpowiednio: $\gamma=0,4, \eta=2,03, G=1,45$. W kolejnym przedziale częstości (> 50\%) znalazło się dziewięć relacji podobnych, które utworzyły cztery podgrafy. Zlokalizowane są one w obrębie: południowej części Pojezierza Pomorskiego, zachodniej części Pojezierza Mazurskiego, Pojezierza i Niziny Wielkopolskiej oraz Roztocza i Kotliny Sandomierskiej. W grafie największego podobieństwa w półroczu ciepłym w warunkach cyrkulacji cyklonalnej zidentyfikowano tylko jedną relację podobną (ryc. 5). Przecina ona Pojezierze Krajeńskie i łączy stacje ChojniceWitosław. Wzdłuż powyższej krawędzi podobne cechy reżimu opadowego identyfikowano z częstością większą od $60 \%$ (62,5\%). Skonstruowany graf charakteryzuje się minimalną spójnością, a poszczególne wskaźniki stopnia spójności przyjęły następujące wartości: $\gamma=0,01, \eta=32,0, G=2,39$.

\section{Półrocze chłodne}

Liczba krawędzi podobnych w wyznaczonych przedziałach częstości oraz ich rozkład przestrzenny w półroczu chłodnym różni się od liczby relacji podobieństwa i ich rozkładu w ciepłym okresie roku. Średnia częstość pojawiania się cech podobieństwa opadowego wzdłuż badanych relacji w chłodnym okresie roku wynosi $62,2 \%$. W trzech najniższych przedziałach częstości $>10 \%,>20 \%,>30 \%$ zidentyfikowano w polu opadowym po 75 krawędzi podobieństwa. Utworzone dla tych przedziałów sieci grafowe są grafami spójnymi (tab. 7). Na wyższym poziomie częstości (>40\%) odnotowano 72 relacje podobne. Trzy krawędzie niepodobieństwa pluwiometrycznego zlokalizowane są w różnych rejonach kraju (ryc. 6). Pierwsza znajduje się w obrębie wschodniej części Pojezierza Pomorskiego (Łeba-Elblag). Druga krawędź ciągnie się wzdłuż zachodniej granicy Polski, przecinając między innymi Nizinę Śląską (Słubice-Jelenia Góra). Natomiast trzecia relacja niepodobieństwa łączy stacje Racibórz i Zakopane. Spójność powstałej sieci grafowej wyrażona odpowiednimi wskaźnikami zbliżona jest do ich wartości maksymalnych (tab. 7). W kolejnym przedziale podobieństwa ( $>50 \%$ ) odnotowano 65 krawędzi podobnych. 

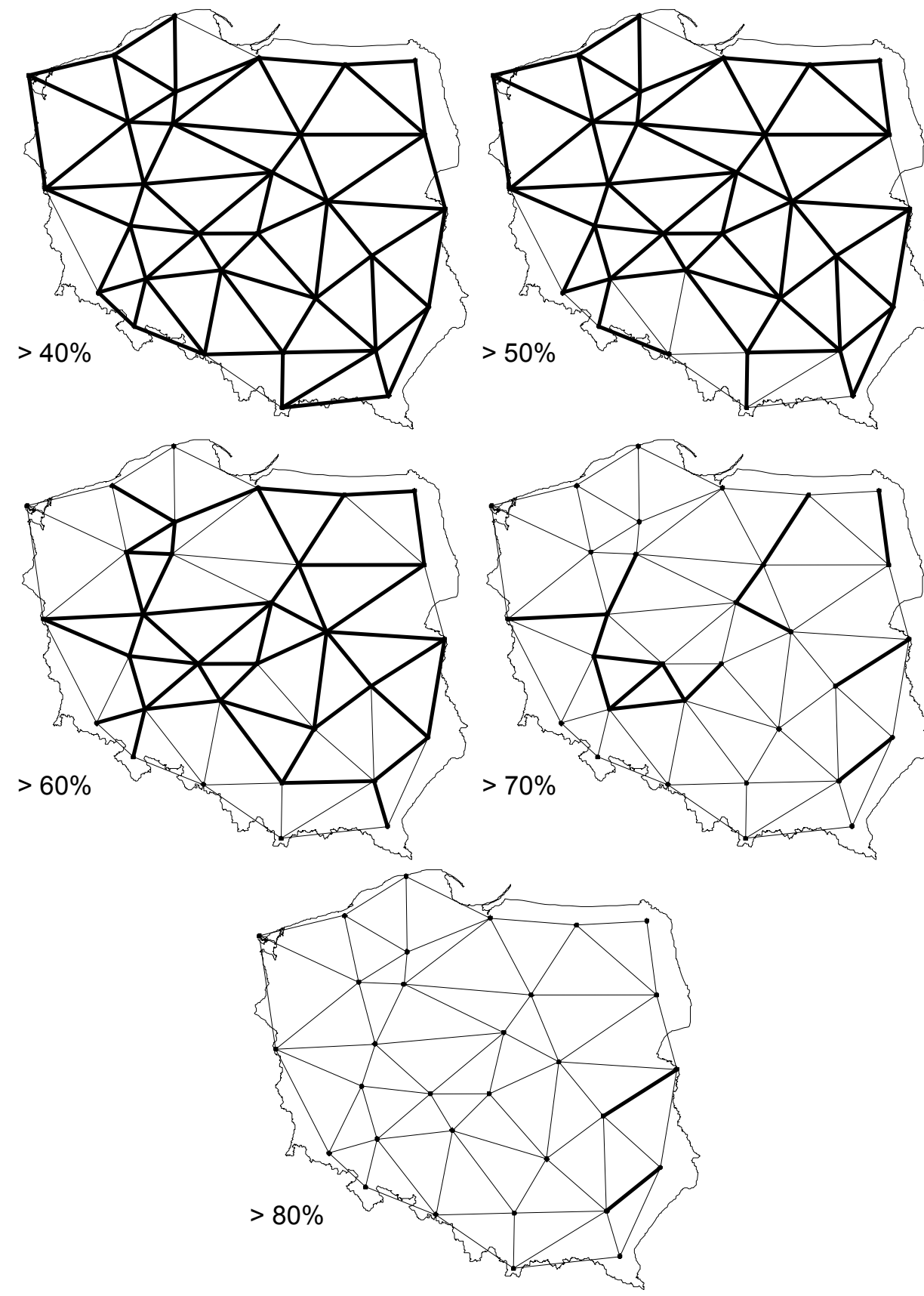

Ryc. 6. Krawędzie o różnej częstości podobieństwa opadowego w warunkach cyrkulacji cyklonalnej - półrocze chłodne

Fig. 6. Edges showing different frequency of precipitation similarity under cyclonic circulationcold half-year 
$\mathrm{Na}$ większości obszaru tworzą one zwartą strukturę, która poprzerywana jest krawędziami niepodobieństwa opadowego przebiegającymi głównie przez: obszary Wyżyny Śląskiej, Pogórza Karpackiego i Karpat oraz Przedgórza Sudeckiego (ryc. 6). Utworzony graf charakteryzuje się stosunkowo dużą spójnością, czego odzwierciedleniem są obliczone wartości wskaźników: $\gamma=0,87$, $\eta=1,48, G=0,32$. W grafie utworzonym przez krawędzie podobieństwa występujące z częstością $>60 \%$ zlokalizowano 47 relacji. Skoncentrowane są one przede wszystkim na nizinnych terenach środkowej Polski z licznymi odgałęzieniami $\mathrm{w}$ kierunku północno-wschodnim i południowo-wschodnim. Na obszarach podgórskich i górskich jedynie krawędzie Wrocław-Jelenia Góra i Wrocław-Kłodzko w rejonie Sudetów oraz Rzeszów-Lesko w obrębie Pogórza Karpackiego wykazały podobne cechy reżimu opadowego. $Z$ kolei na wybrzeżu podobne cechy stosunków opadowych stwierdzono jedynie wzdłuż relacji Koszalin-Chojnice (ryc. 6). Na kolejnym poziomie częstości (> 70\%) znalazło się 15 relacji, które utworzyły pięć podgrafów. Najbardziej rozbudowany, składający się z dziewięciu krawędzi, znajduje się na styku nizin Wielkopolskiej i Śląskiej. Pozostałe położone są we wschodniej Polsce. Skonstruowany dla tego przedziału częstości graf wyróżnia się niskim stopniem spójności (tab. 7). W sieci grafowej najczęstszego podobieństwa odnotowano dwie relacje podobne, położone na terenie Wyżyny Lubelskiej i Roztocza (ryc. 6). Identyczne cechy reżimu opadowego wystapiły wzdłuż tych krawędzi z częstością wynoszącą $82 \%$. Wartości wskaźników stopnia spójności tej sieci to odpowiednio: $\gamma=0,03, \eta=16,5, G=2,35$.

\section{Relacje podobieństwa w sytuacjach o charakterze pośrednim}

\section{Rok}

W warunkach cyrkulacji pośredniej częstość występowania relacji podobieństwa w polu opadowym wynosi $58,7 \%$. W trzech najniższych rozpatrywanych przedziałach częstości $(>10 \%,>20 \%,>30 \%)$ odnotowano po 75 krawędzi podobnych. Utworzone w tym przypadku sieci grafowe są grafami spójnymi (tab. 8). Z częstością większą od $40 \%$ zidentyfikowano w polu opadowym 72 krawędzie podobieństwa. Odmienne cechy reżimu pluwiometrycznego stwierdzono między parami stacji położonymi na południowych i południowo-wschodnich krańcach sieci (Racibórz-Zakopane, Lesko-Zakopane, ZamośćLesko (ryc. 7). Spójność powstałego grafu opisują następujące wskaźniki: $\gamma=0,96, \eta=1,43, G=0,1$. W sieci utworzonej przez relacje podobieństwa występujące w badanym polu z częstością większą od $50 \%$ znalazły się 64 krawędzie. Obok kontrastów niepodobieństwa zlokalizowanych w południowo-wschodniej Polsce relacje o takim charakterze zidentyfikowano również na obszarach pojezierzy Pomorskiego i Wielkopolskiego oraz w obrębie Wyży- 
Tabela 8. Spójność grafów o różnej częstości podobieństwa opadowego w warunkach cyrkulacji pośredniej

Table 8. Consistency of graphs showing different frequency of precipitation similarity under intermediate circulation - year

\begin{tabular}{|c|c|c|c|c|c|c|c|c|c|}
\hline \multirow{3}{*}{$\begin{array}{c}\text { Częstość } \\
\text { podobień- } \\
\text { stwa } \\
{[\%]}\end{array}$} & \multicolumn{3}{|c|}{$\begin{array}{l}\text { Półrocze ciepłe } \\
{[\mathrm{V}-\mathrm{X}]}\end{array}$} & \multirow{2}{*}{\multicolumn{3}{|c|}{$\begin{array}{c}\text { Półrocze chłodne } \\
{[\mathrm{XI}-\mathrm{IV}]}\end{array}$}} & \multicolumn{3}{|c|}{ Rok } \\
\hline & \multirow[b]{2}{*}{$\gamma$} & & & & & & & & \\
\hline & & $\eta$ & $G$ & $\gamma$ & $\eta$ & $G$ & $\gamma$ & $\eta$ & $G$ \\
\hline$>10$ & 1 & 1,41 & 0 & 1 & 1,41 & 0 & 1 & 1,41 & 0 \\
\hline$>20$ & 0,99 & 1,42 & 0,03 & 1 & 1,41 & 0 & 1 & 1,41 & 0 \\
\hline$>30$ & 0,91 & 1,46 & 0,23 & 1 & 1,41 & 0 & 1 & 1,41 & 0 \\
\hline$>40$ & 0,72 & 1,57 & 0,68 & 0,99 & 1,42 & 0,03 & 0,96 & 1,43 & 0,10 \\
\hline$>50$ & 0,33 & 2,24 & 1,61 & 0,95 & 1,44 & 0,13 & 0,85 & 1,48 & 0,35 \\
\hline$>60$ & 0,15 & 3,82 & 2,06 & 0,77 & 1,53 & 0,55 & 0,37 & 2,11 & 1,52 \\
\hline$>70$ & & & & 0,63 & 1,66 & 0,90 & 0,16 & 3,58 & 2,03 \\
\hline$>80$ & & & & 0,27 & 2,55 & 1,77 & 0,01 & 32,0 & 2,39 \\
\hline$>90$ & & & & 0,07 & 7,2 & 2,26 & & & \\
\hline
\end{tabular}

ny Małopolskiej (ryc. 7). Utworzona sieć charakteryzuje się stosunkowo dużą spójnością, czego wyrażeniem są obliczone wartości wskaźników: $\gamma=0,85$, $\eta=1,48, G=0,35$. W kolejnym grafie utworzonym dla wyższego zakresu częstości podobieństwa ( $>60 \%$ ) znalazło się już tylko 28 krawędzi. Uzyskane dla tej sieci wskaźniki spójności osiagnęły następujące wartości: $\gamma=0,37, \eta=2,11$, $G=1,52$. Krawędzie podobieństwa utworzyły trzy podgrafy (ryc. 7). Na kolejnym poziomie częstości $(>70 \%)$ znalazło się 12 krawędzi podobieństwa opadowego. Trzy podgrafy znajdujące się w tej sieci zbudowane są jedynie z pojedynczych krawędzi (Suwałki-Kętrzyn, Mława-Płock, Puławy-Zamość). Pozostałe dwa położone w obrębie nizin Wielkopolskiej i Śląskiej oraz na Pojezierzu Pomorskim stanowią bardziej rozbudowane struktury (ryc. 7). Wskaźniki stopnia spójności wynoszą odpowiednio: $\gamma=0,16, \eta=3,58, G=2,03$. $\mathrm{Z}$ najwyższą częstością przekraczającą $80 \%$ podobne cechy stosunków opadowych były identyfikowane wzdłuż jednej relacji położonej na obszarze południowo-zachodniej części Pojezierza Mazurskiego, a łączącej stacje Mława i Płock. Wskaźniki stopnia spójności sieci najwyższego podobieństwa przyjęły wartości minimalne: $\gamma=0,01, \eta=32,0, G=2,39$.

\section{Półrocze ciepłe}

W ciepłym okresie roku relacje podobieństwa opadowego pojawiały się w polu opadów ze średnią częstością $48 \%$. Jedynie graf zbudowany z krawędzi podobieństwa występujących z częstością większą od 10\% jest grafem spójnym, czyli zbudowanym z 75 krawędzi podobnych (tab. 8). Już na kolejnym poziomie 

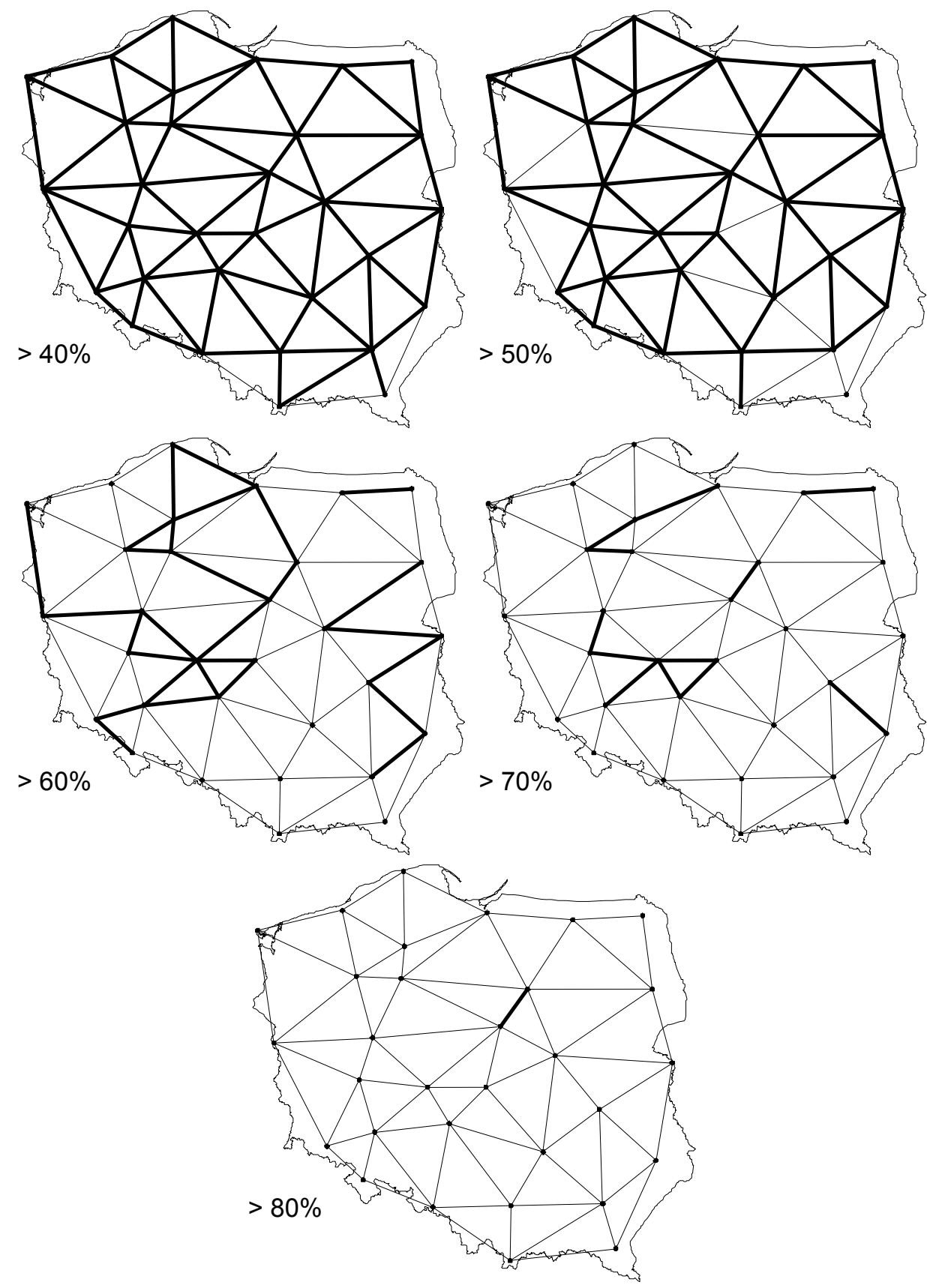

Ryc. 7. Krawędzie o różnej częstości podobieństwa opadowego w warunkach cyrkulacji pośredniej - rok

Fig. 7. Edges showing different frequency of precipitation similarity under intermediate circulation - year 
częstości (> 20\%) zidentyfikowano tylko 74 relacje. Wskaźniki spójności tej sieci zbliżone są do wartości maksymalnych i wynoszą odpowiednio: $\gamma=0,99$, $\eta=1,42, G=0,03$. Cechy niepodobieństwa stosunków opadowych odnotowano wzdłuż krawędzi położonej na obszarze Wyżyny Małopolskiej oraz łączącej stacje Wieluń i Kielce (ryc. 8). Z częstością przekraczającą 30\% odnotowano 68 krawędzi podobnych. W tym przypadku cechy niepodobieństwa ujawniły się wzdłuż krawędzi położonych w południowo-wschodniej Polsce oraz w zachodniej części Pojezierza Mazurskiego i Niziny Mazowieckiej (ryc. 8). Z kolei z częstością większą od $40 \%$ pojawiały się w polu opadów 54 relacje podobne. $\mathrm{W}$ ich rozkładzie przestrzennym zwraca uwagę wyraźnie zarysowana południowa granica występowania relacji podobnych, przebiegająca wzdłuż krawędzi Racibórz-Kraków-Rzeszów-Zamość (ryc. 8). Spójność utworzonego grafu opisują wartości następujących wskaźników: $\gamma=0,72, \eta=1,57, G=0,68$. Z częstością powyżej $50 \%$ podobieństwo opadowe odnotowano wzdłuż 25 relacji. Wartości wskaźników spójności otrzymane dla utworzonego przez te relacje grafu wynoszą odpowiednio: $\gamma=0,33, \eta=2,24, G=1,61$. Krawędzie podobne skupione są w czterech podgrafach zlokalizowanych w pasie pojezierzy, na Nizinie Śląskiej oraz w obrębie Wyżyny Lubelskiej (ryc. 8). Z kolei w sieci grafowej zbudowanej z relacji najwyższego podobieństwa widocznych jest pięć podgrafów składających się ogółem z 11 relacji. Obliczone dla tej sieci wskaźniki spójności wynoszą: $\gamma=0,15, \eta=3,82, G=2,06$. Relacje podobne zidentyfikowano w różnych częściach kraju: na pojezierzach Pomorskim i Mazurskim, nizinach Wielkopolskiej i Śląskiej oraz w Sudetach. Z największą częstością (70\%) podobne cechy reżimu opadowego odnotowano wzdłuż trzech krawędzi: Chojnice-Wałcz, Mława-Płock, Kalisz-Wrocław.

\section{Półrocze chłodne}

W chłodnym okresie roku średnia częstość występowania podobnych cech reżimu pluwiometrycznego wzdłuż krawędzi łączących parę stacji wyniosła $71,3 \%$. W trzech najniższych rozpatrywanych przedziałach częstości podobieństwa opadowego $(>10 \%,>20 \%,>30 \%)$ odnotowano po 75 relacji podobnych (100\% wyjściowej liczby krawędzi). Utworzone dla tych przedziałów częstości sieci są grafami spójnymi (tab. 8). Na kolejnym poziomie częstości (> 40\%) znalazły się 74 relacje podobne. Obliczone dla skonstruowanego grafu wartości wskaźników stopnia spójności zbliżone są do wartości maksymalnych (tab. 8). Z najmniejszą częstością (35,3\%) identyczne cechy reżimu opadowego występowały wzdłuż relacji położonej we wschodniej części Pojezierza Mazurskiego, a łączącej stacje Kętrzyn i Białystok (ryc. 9). Na kolejnym wyższym poziomie częstości zidentyfikowano w polu opadów 71 relacji podobieństwa. Spójność powyższego grafu wyrażona wartością poszczególnych wskaźników wyniosła: $\gamma=0,95, \eta=1,44, G=0,13$. Kolejne relacje niepodobieństwa opadowego zlokalizowano w południowo-wschodniej Polsce w obrębie Pogórza Karpackiego. 

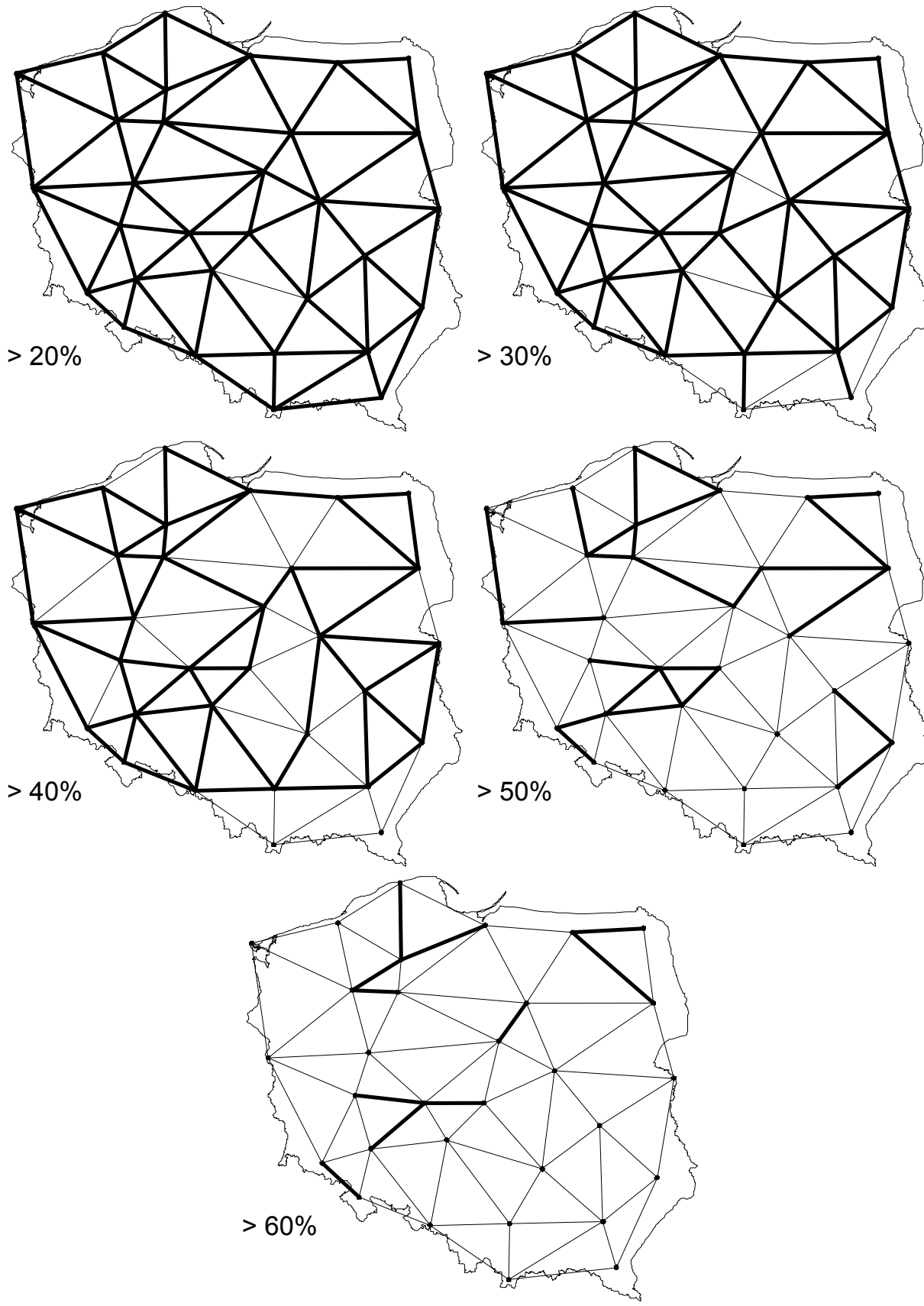

Ryc. 8. Krawędzie o różnej częstości podobieństwa opadowego w warunkach cyrkulacji pośredniej - półrocze ciepłe

Fig. 8. Edges showing different frequency of precipitation similarity under intermediate circulation - warm half-year 
$\mathrm{W}$ grafie zbudowanym $\mathrm{z}$ relacji podobnych występujących $\mathrm{w}$ badanym polu $\mathrm{z}$ częstością przekraczającą $60 \%$ odnotowano 58 krawędzi. Relacje podobieństwa w dużej liczbie występują we wschodniej części Pojezierza Pomorskiego, na Pojezierzu Mazurskim, na Nizinie i Pojezierzu Wielkopolskim oraz na Wyżynie Lubelskiej (ryc. 9). Zbudowany dla tego przedziału częstości graf charakteryzuje się stosunkowo dużym stopniem spójności: $\gamma=0,77, \eta=1,53, G=0,55$. W wyższym przedziale częstości (> 70\%) znalazło się 47 krawędzi podobnych. Relacje te skoncentrowane są głównie: we wschodniej części Pojezierza Pomorskiego, na Pojezierzu i Nizinie Wielkopolskiej i północnej części Niziny Śląskiej. Od strefy tej rozchodzą się liczne rozgałęzienia (ryc. 9). Wskaźniki spójności przyjęły w tym przypadku następujące wartości: $\gamma=0,63, \eta=1,66$, $G=0,90$. Z częstością większą od $80 \%$ odnotowano 20 krawędzi podobnych, które utworzyły trzy podgrafy (ryc. 9). Spójność powstałej struktury grafowej wyniosła: $\gamma=0,27, \eta=2,55, G=1,77$. W grafie najczęstszego podobieństwa zidentyfikowano pięć krawędzi podobnych. Relacje te zgrupowane są w trzech podgrafach. Dwa z nich zbudowane są z pojedynczych relacji zlokalizowanych na obszarze południowej części Pojezierza Pomorskiego (Wałcz-Witosław) oraz na terenie Pojezierza i Niziny Wielkopolskiej (Poznań-Leszno). Trzeci tworzy rozciagnięta strefę ciagnnącą się od Elbląga na północy przez Mławę, Płock po Kalisz (ryc. 9).

\section{Relacje podobieństwa w sytuacjach o charakterze antycyklonalnym}

\section{Rok}

Częstość pojawiania się w polu opadów relacji podobieństwa $\mathrm{w}$ warunkach cyrkulacji antycyklonalnej jest bardzo duża i wynosi 70,5\%. Wartości skrajne zawierają się w zakresie od $51,7 \%$ w przypadku najmniejszej częstości (co oznacza, że na 147 rozpatrywanych zdarzeń w 76 reżim opadów wzdłuż badanej krawędzi wykazywał cechy podobne) do $82,3 \%$ w przypadku najwyższej częstości (co daje 121 przypadków wystąpienia podobieństwa reżimu opadów). Wartości graniczne charakteryzują odpowiednio relacje zachodzące wzdłuż kontrastów łączących stacje Racibórz i Zakopane oraz Warszawę i Puławy. Krawędzie podobne pojawiające się $\mathrm{w}$ polu opadów z częstością: $>10 \%,>20 \%,>30 \%$, $>40 \%,>50 \%$ utworzyły spójne sieci grafowe składające się z 75 relacji podobieństwa opadowego (tab. 9). Dla grafu skonstruowanego z krawędzi, wzdłuż których identyczne cechy stosunków pluwiometrycznych stwierdzano z częstością większą od $60 \%$, obliczone wskaźniki spójności sieci przyjęły wartości niemal maksymalne: $\gamma=0,95, \eta=1,44, G=0,13$. W tym przypadku w polu opadów znalazło się 71 krawędzi podobnych, a jego duża spójność zakłócona jest jedynie w strefie południowej przez cztery relacje niepodobieństwa łączące Zakopane ze stacjami sąsiednimi (ryc. 10). Z częstością większą od $70 \%$ odnotowano 

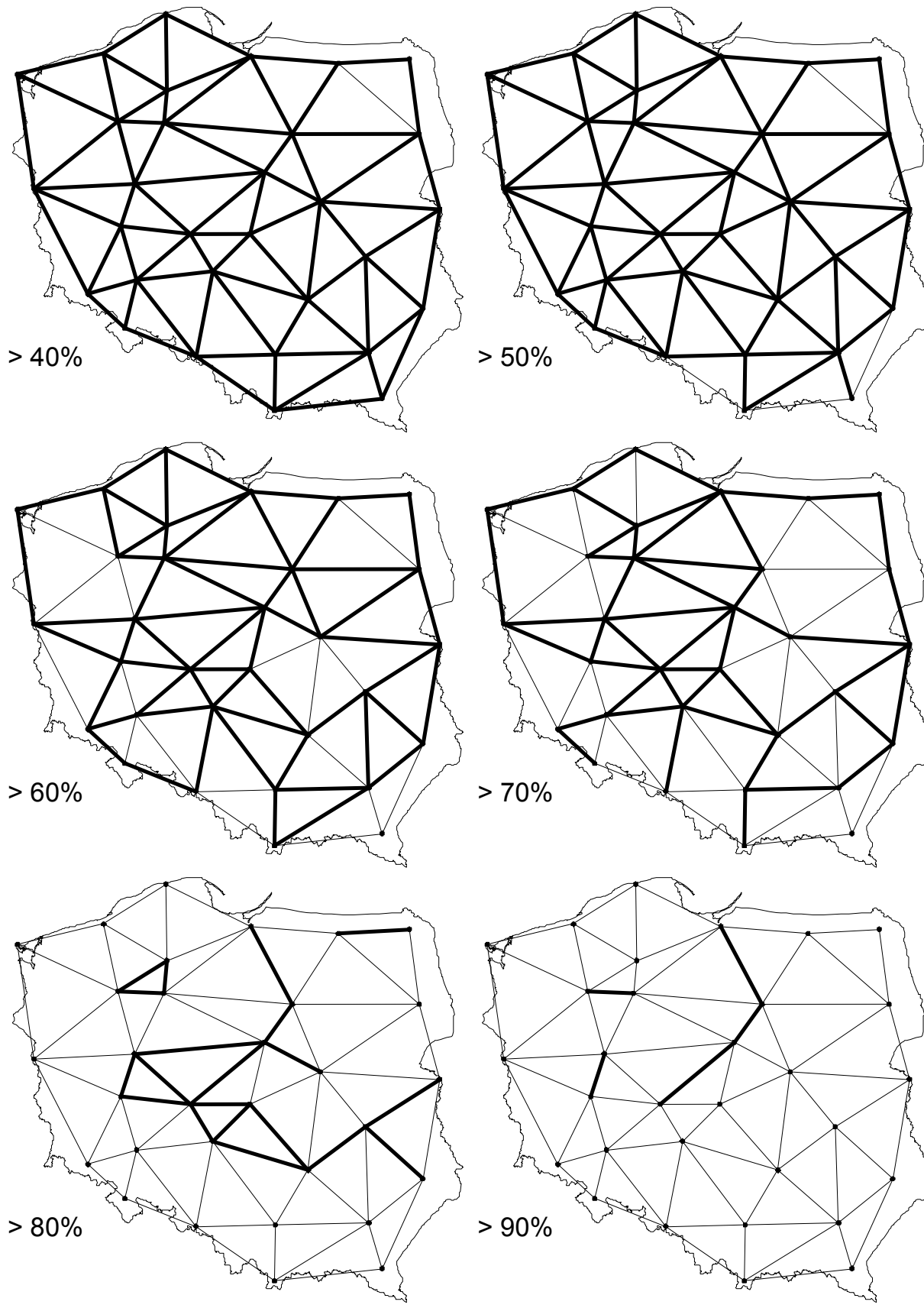

Ryc. 9. Krawędzie o różnej częstości podobieństwa opadowego w warunkach cyrkulacji pośredniej - półrocze chłodne

Fig. 9. Edges showing different frequency of precipitation similarity under intermediate circulation - cold half-year 
Tabela 9. Spójność grafów o różnej częstości podobieństwa opadowego w warunkach cyrkulacji antycyklonalnej

Table 9. Consistency of graphs showing different frequency of precipitation similarity under anti-cyclonic circulation

\begin{tabular}{|c|c|c|c|c|c|c|c|c|c|}
\hline \multirow{3}{*}{$\begin{array}{c}\text { Częstość } \\
\text { podobień- } \\
\text { stwa } \\
{[\%]}\end{array}$} & \multicolumn{3}{|c|}{$\begin{array}{l}\text { Półrocze ciepłe } \\
{[\mathrm{V}-\mathrm{X}]}\end{array}$} & \multirow{2}{*}{\multicolumn{3}{|c|}{$\begin{array}{c}\begin{array}{c}\text { Półrocze chłodne } \\
{[X I-I V]}\end{array} \\
\text { Wskaźniki spójności }\end{array}$}} & \multicolumn{3}{|c|}{ Rok } \\
\hline & \multirow[b]{2}{*}{$\gamma$} & \multirow[b]{2}{*}{$\eta$} & \multirow[b]{2}{*}{$G$} & & & & \multirow[b]{2}{*}{$\gamma$} & \multirow[b]{2}{*}{$\eta$} & \multirow[b]{2}{*}{$G$} \\
\hline & & & & $\gamma$ & \multirow{2}{*}{$\frac{\eta}{1,41}$} & $G$ & & & \\
\hline$>10$ & 1 & 1,41 & 0 & 1,00 & & 0,0 & 1 & 1,41 & 0 \\
\hline$>20$ & 1 & 1,41 & 0 & 1,00 & 1,41 & 0,0 & 1 & 1,41 & 0 \\
\hline$>30$ & 1 & 1,41 & 0 & 1,00 & 1,41 & 0,0 & 1 & 1,41 & 0 \\
\hline$>40$ & 0,95 & 1,44 & 0,13 & 1,00 & 1,41 & 0,0 & 1 & 1,41 & 0 \\
\hline$>50$ & 0,85 & 1,48 & 0,35 & 1,00 & 1,41 & 0,0 & 1 & 1,41 & 0 \\
\hline$>60$ & 0,49 & 1,84 & 1,23 & 1,00 & 1,41 & 0,0 & 0,95 & 1,44 & 0,13 \\
\hline$>70$ & 0,04 & 11,33 & 2,32 & 0,99 & 1,42 & 0,03 & 0,6 & 1,69 & 0,97 \\
\hline$>80$ & & & & 0,59 & 1,7 & 1,0 & 0,03 & 16,5 & 2,35 \\
\hline$>90$ & & & & 0,01 & 32,0 & 2,39 & & & \\
\hline
\end{tabular}

45 krawędzi podobnych, co stanowi $60 \%$ początkowej liczby badanych relacji. Utworzony graf charakteryzuje się średnim stopniem spójności: $\gamma=0,6$, $\eta=1,69, G=0,97$. Relacje podobieństwa skupione są w dwóch wyraźnych strefach: zachodniej - obejmującej część Pojezierza Pomorskiego, Pojezierza i Niziny Wielkopolskiej oraz fragment pasma Sudetów wzdłuż krawędzi Jelenia Góra-Kłodzko i wschodniej - ciągnącej się na południe od strefy Kętrzyn-Suwałki (ryc. 10). Całkowicie odmienną strukturę pola opadów przedstawia graf utworzony z relacji najwyższego podobieństwa występujących z częstością większą od $80 \%$. Sieć grafową tworzą w tym przypadku dwie relacje zależne w wierzchołku Warszawa, a łączące stacje Mława-Warszawa i Warszawa-Puławy. Małą spójność powyższej sieci grafowej opisują wartości następujących wskaźników: $\gamma=0,03, \eta=16,5, G=2,35$.

\section{Półrocze ciepłe}

W półroczu ciepłym, w warunkach cyrkulacji antycyklonalnej, relacje podobieństwa opadowego identyfikowano w polu opadowym z częstością 59,3\%. $\mathrm{W}$ trzech najniższych rozpatrywanych przedziałach częstości $(>10 \%,>20 \%$, $>30 \%$ ) odnotowano po 75 relacji podobnych, stąd utworzone dla tych zakresów podobieństwa sieci są grafami spójnymi (tab. 9).

$\mathrm{Na}$ kolejnym wyższym poziomie częstości (> 40\%) znalazło się $71 \mathrm{kra}-$ wędzi podobnych. Najmniejszym podobieństwem $(34,3 \%)$ charakteryzowały się stosunki pluwiometryczne wzdłuż relacji przechodzącej przez Beskidy 

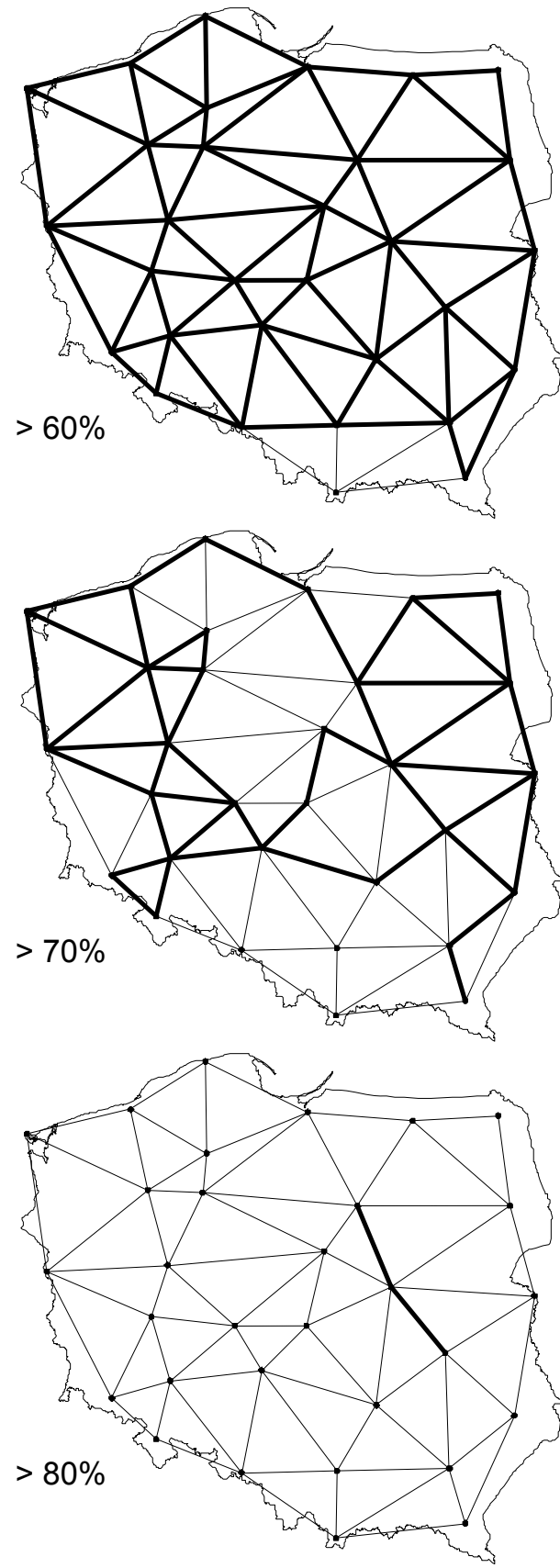

Ryc. 10. Krawędzie o różnej częstości podobieństwa opadowego w warunkach cyrkulacji antycyklonalnej - rok

Fig. 10. Edges showing different frequency of precipitation similarity under anti-cyclonic circulation - year 
Zachodnie, Racibórz-Zakopane. Trzy pozostałe krawędzie z podobieństwem opadowym w półroczu ciepłym mniejszym od $40 \%$ łączą Zakopane z Krakowem, Rzeszowem i Leskiem (ryc. 11). Wartości obliczonych wskaźników spójności utworzonego grafu $\mathrm{w}$ niewielkim stopniu odbiegają od ich wartości maksymalnych (tab. 9). W przedziale częstości $>50 \%$ odnotowano 64 relacje podobne. Relacje niepodobieństwa opadowego zlokalizowane są w południowo-wschodniej oraz w środkowej Polsce. Wskaźniki spójności tego grafu wynoszą: $\gamma=0,85, \eta=1,48, G=0,35$. Kolejny graf zbudowany z krawędzi mieszczących się $\mathrm{w}$ przedziale częstości $>60 \%$ składa się z 37 relacji. Krawędzie podobne utworzyły trzy podgrafy. Pierwszy z nich obejmuje 23 krawędzie położone wzdłuż zachodniej granicy Polski na obszarze: południowej części Pojezierza Pomorskiego, Pojezierza i Niziny Wielkopolskiej, Niziny Śląskiej oraz wzdłuż Sudetów. Drugi z podgrafów zlokalizowany jest na obszarze północno-wschodniej Polski, sięgając najdalej na południe po stacje Katowice i Zamość. Trzeci z podgrafów położony jest we wschodniej części Pojezierza Pomorskiego i stanowi drogę łączącą stacje Łeba i Elblagg (ryc. 11). Spójność powstałego grafu określona wartościami obliczonych wskaźników wyniosła odpowiednio: $\gamma=0,49, \eta=1,84, G=1,23$. W grafie najczęstszego podobieństwa ( $>70 \%$ ) zidentyfikowano trzy krawędzie podobne, a ich rozkład przestrzenny przedstawiono za pomocą ryciny 11 .

\section{Półrocze chłodne}

W warunkach cyrkulacji antycyklonalnej w półroczu chłodnym relacje podobne pojawiały się $\mathrm{w}$ polu opadów $\mathrm{z}$ bardzo wysoką częstością $80,7 \%$. Aż w sześciu wydzielonych przedziałach częstości $(>10 \%,>20 \%,>30 \%,>40 \%$, $>50 \%,>60 \%$ ) odnotowano po 75 krawędzi podobnych, a skonstruowane dla tych zakresów częstości sieci grafowe są odwzorowaniem grafu wyjściowego (tab. 9). Z najmniejszą częstością (66,2\%) te same cechy reżimu opadowego identyfikowano wzdłuż krawędzi łączącej Racibórz i Zakopane. Jest to jedyna relacja, której zabrakło w grafie zbudowanym z relacji podobieństwa opadowego występujących z częstością większą od 70\% (ryc. 12). Dużą spójność tego grafu opisują następujące wartości wskaźników spójności: $\gamma=0,99, \eta=1,42$, $G=0,03$. W kolejnym przedziale podobieństwa ( $>80 \%$ ) odnotowano 44 krawędzie podobne, które rozrzucone są po całym obszarze Polski. W grafie najwyższego podobieństwa (>90\%) znalazła się tylko jedna krawędź, poprowadzona w obrębie Niziny Północno- i Środkowomazowieckiej, a łącząca stacje Mława i Warszawa (ryc. 12). Wzdłuż tej relacji identyczne cechy stosunków pluwiometrycznych były stwierdzane z częstością $93,5 \%$. Utworzony graf charakteryzuje się minimalną spójnością: $\gamma=0,01, \eta=32,0, G=2,39$. 

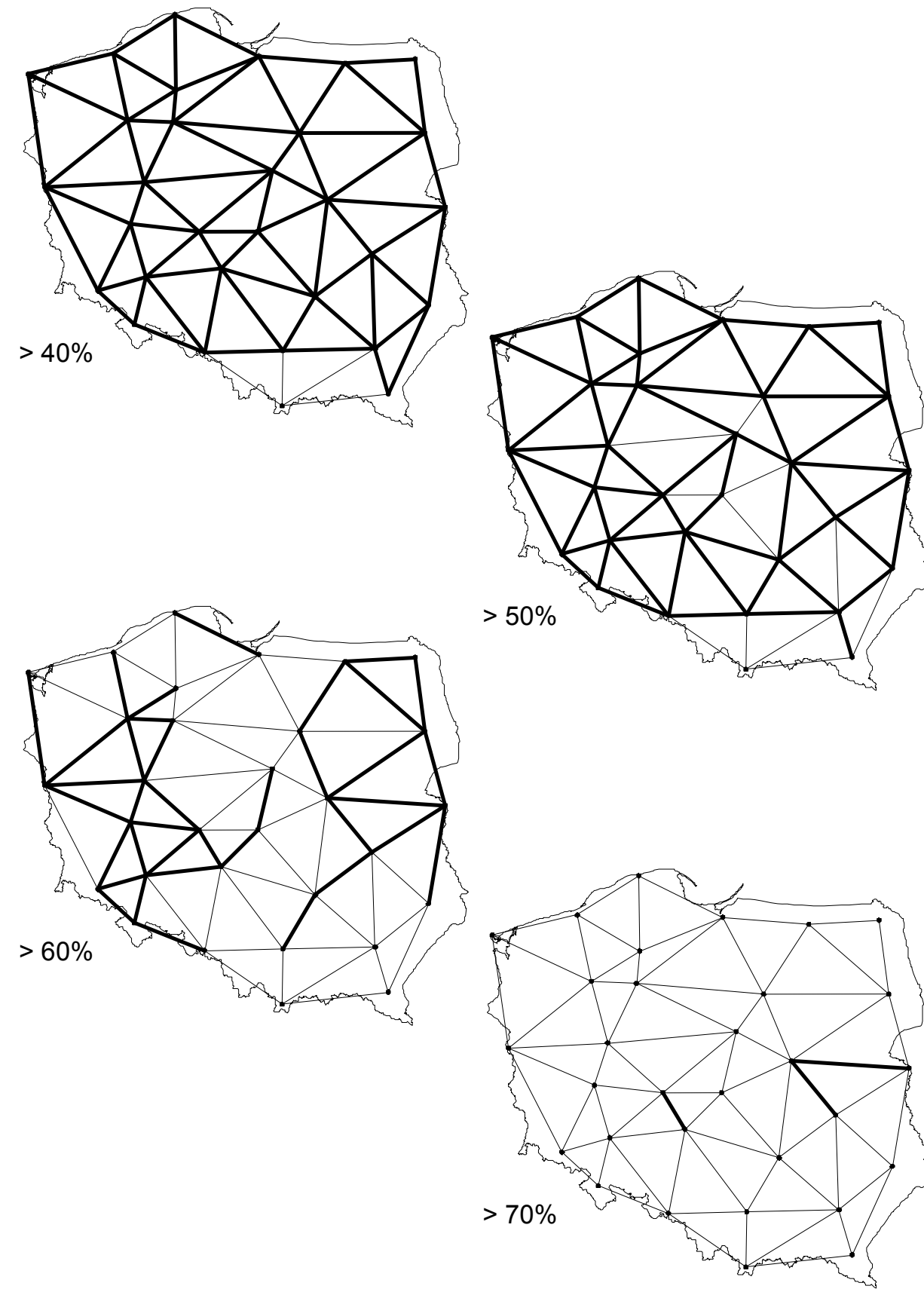

Ryc. 11. Krawędzie o różnej częstości podobieństwa opadowego w warunkach cyrkulacji antycyklonalnej - półrocze ciepłe

Fig. 11. Edges showing different frequency of precipitation similarity under anti-cyclonic circulation - warm half-year 

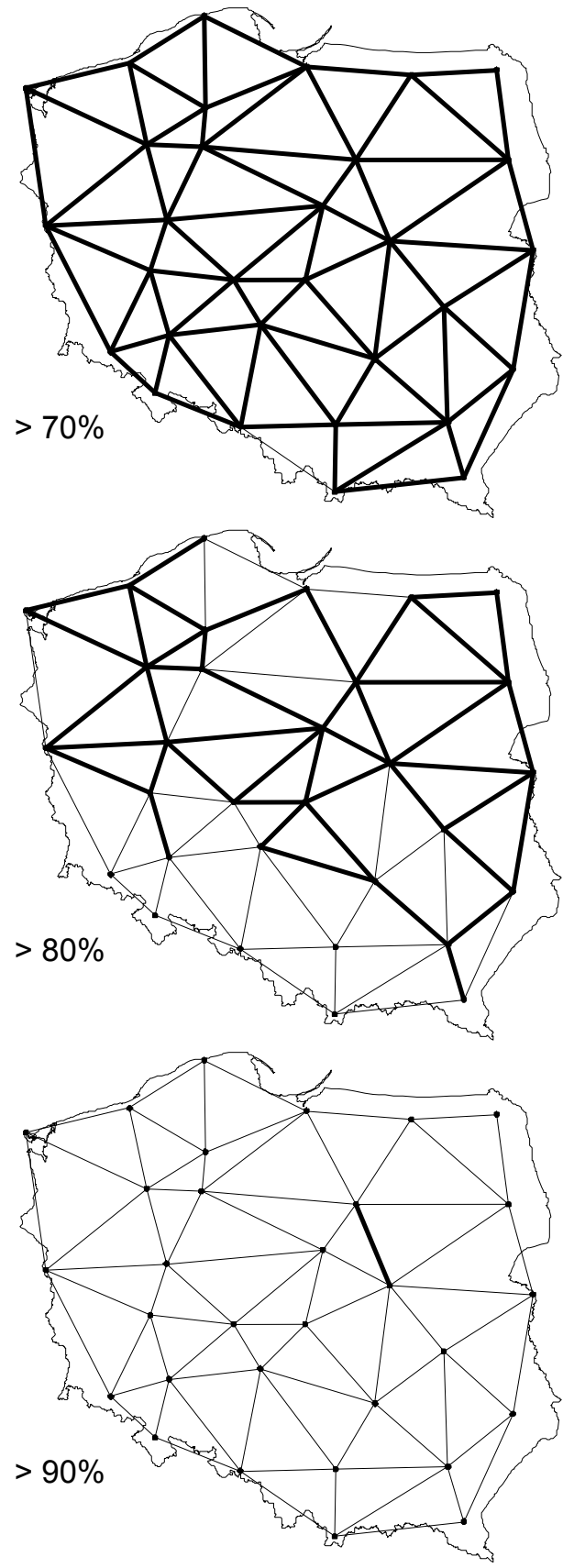

Ryc. 12. Krawędzie o różnej częstości podobieństwa opadowego w warunkach cyrkulacji antycyklonalnej - półrocze chłodne

Fig. 12. Edges showing different frequency of precipitation similarity under anti-cyclonic circulation - cold half-year 


\section{PODSUMOWANIE I WNIOSKI}

Podstawą badań wpływu charakteru cyrkulacyjnych na strukturę przestrzenną pola opadów atmosferycznych Polski były codzienne dane pluwiometryczne dla 31 stacji meteorologicznych oraz katalog typów cyrkulacji opublikowany przez M. Stępniewską-Podrażkę. Analizie poddano wszystkie okresy 7-dniowe lub dłuższe, które w wieloleciu 1951-1990 cechowały się wystapieniem identycznych typów cyrkulacji. Posiadane dane pluwiometryczne pozwoliły scharakteryzować w każdej miejscowości reżim pluwiometryczny wyróżnionych okresów z punktu widzenia trzech wskaźników: sumy opadów, deszczowości, obfitości opadów. Przedmiotem badań były relacje podobieństwa pluwiometrycznego między sąsiednimi punktami (stacjami) w określonych warunkach cyrkulacji atmosfery. Kwestie związane z celem podjętych badań rozpatrzono $\mathrm{z}$ uwzględnieniem elementów teorii grafów.

Poniżej przedstawiono wybrane wyniki ukazujące charakter organizacji strukturalnej pola opadów w zależności od panujących warunków cyrkulacji atmosfery.

1) Zróżnicowanie podobieństwa pola opadów ulega zakłóceniom w różnym stopniu. Liczba relacji podobnych w utworzonych sieciach grafowych wahała się od 9 do 75 .

2) Przypadki wystapienia pełnego podobieństwa związane są jedynie z sytuacjami cyrkulacji antycyklonalnej i wystapiły w typach cyrkulacji SEa, Sa i Oa.

3) Stopień podobieństwa pola opadów ulega zróżnicowaniu w zależności od charakteru cyrkulacji. Średnia częstość identyfikowania cech podobieństwa opadowego wzdłuż badanych krawędzi jest najniższa w przypadku cyrkulacji cyklonalnej i wynosi $52,2 \%$, w warunkach cyrkulacji pośredniej wskaźnik ten przyjął wartość $58,7 \%$, a w sytuacjach antycyklonalnych $70,5 \%$.

4) W ujęciu sezonowym, zarówno w warunkach cyrkulacji cyklonalnej, pośredniej, jak i antycyklonalnej z mniejszą częstością podobieństwo pluwiometryczne wzdłuż wyznaczonych relacji stwierdzane jest w półroczu ciepłym. W zdarzeniach cyklonalnych średni stopień podobieństwa wszystkich krawędzi w tym okresie roku wynosi zaledwie $39,1 \%$, a w sytuacjach antycyklonalnych 59,3\%. Półrocze chłodne charakteryzuje zdecydowanie wyższa stabilność strukturalnych właściwości pola opadów. W sytuacjach o charakterze cyklonalnym $\mathrm{w}$ chłodnym okresie roku przeciętna, $\mathrm{z}$ jaką identyfikowano cechy podobieństwa opadowego, wyniosła $62,2 \%$, a w warunkach cyrkulacji antycyklonalnej aż 80,7\%.

5) Przyjęta procedura tworzenia sekwencji grafów tylko z tych relacji sieci, wzdłuż których pozytywne relacje podobieństwa opadowego zachodziły z częstością kolejno $>10 \%,>20 \%$ itd., pozwoliła na graficzne przedstawienie dynamiki zmian strukturalnych zachodzących w obrębie badanego 
pola opadów Polski. Stwierdzono, iż w miarę przechodzenia na wyższe poziomy częstości następuje spadek liczby krawędzi podobieństwa. Różne jest jednak tempo dezintegracji cech podobieństwa pola opadów. Na przykład w ujęciu rocznym, w przypadkach cyklonalnych, podobieństwo opadowe wzdłuż wszystkich wyznaczonych krawędzi uzyskano jedynie w dwóch najniższych przedziałach częstości podobieństwa (>10\% i 20\%), w sytuacjach pośrednich w trzech przedziałach $(>10 \%,>20 \%,>30 \%)$ a w sytuacjach antycyklonalnych aż w pięciu wyróżnionych przedziałach częstości $(>10 \%$, $>20 \%,>30 \%,>40 \%,>50 \%$ ).

6) Wykonane ujęcia sezonowe potwierdziły, że półrocze ciepłe charakteryzuje większa dynamika dezintegracji przestrzennej podobieństwa pola opadów $\mathrm{w}$ porównaniu z chłodnym okresem roku zarówno w warunkach cyrkulacji cyklonalnej jak i pośredniej oraz antycyklonalnej.

7) Przedstawione w pracy kartograficzne przykłady przestrzennego zróżnicowania obszaru Polski w zakresie częstości identyfikowania podobieństwa opadowego pozwoliły na wyeksponowanie w wymiarze geograficznym stref i obszarów zarówno z najmniejszą, jak i największą częstością podobieństwa pluwialnego $\mathrm{w}$ różnych warunkach cyrkulacyjnych. $\mathrm{W}$ ujęciu rocznym, w sytuacji cyrkulacji cyklonalnej, z najmniejszą częstością cechy podobieństwa opadowego identyfikowano wzdłuż strefy Racibórz-Zakopane $(24,4 \%)$, a z największą częstością wzdłuż relacji Zamość-Rzeszów (71,1\%). W warunkach cyrkulacji pośredniej, ekstremalne wartości uzyskano odpowiednio dla krawędzi Racibórz-Zakopane i Zamość-Lesko (32,4\% - minimalna częstość) oraz strefy łączącej stacje Mława i Płock $(81,1 \%$ maksymalna częstość). W przypadku cyrkulacji antycyklonalnej wartości skrajne zawierają się w zakresie od 51,7\% (Racibórz-Zakopane) do 83,3\% (Warszawa-Puławy).

Zastosowane metody grafowego badania cech strukturalnych pola opadów potwierdziły, iż stanowią one przydatne i efektywne narzędzie badawcze zwłaszcza w przypadku analiz przestrzennych o charakterze relacyjnym. Przedstawione przykłady ujęć grafowych mniej lub bardziej jednoznacznie udowadniaja, iż o strukturze przestrzennej pola opadów Polski z punktu widzenia relacji pluwiometrycznego podobieństwa decydują elementy cyrkulacji, a zasięg przestrzenny tego oddziaływania jest zmienny sezonowo.

\section{LITERATURA}

Alfierova Z., Ezzeva W., 1971: Primienienie teorii grafov v ekonomiecskich rascetach, Moskwa (tłum. pol., 1974: Zastosowanie teorii grafów w rachunku ekonomicznym, Warszawa).

Andrzejczak W., 2003: Problem identyfikacji wierzchołków grafu sieci transportowej na przykładzie sieci drogowej powiatu jarocińskiego. [W:] H. Rogacki (red.), Problemy interpretacji 
wyników metod $i$ metod badawczych stosowanych w geografii spoteczno-ekonomicznej $i$ gospodarce przestrzennej, Bogucki Wyd. Nauk., Poznań.

Baumgart-Kotarba M., Sobański M., 1978: Zastosowanie grafów o wielocechowej typologii fizycznogeograficznej na przyktadzie wybranego obszaru fliszowego, Zesz. Nauk. UJ, Pr. Geogr., z. 45.

Chojnicki Z., 1988: Basic philosophical and methodological problems of space and time, Concepts and Methods in Geogr., 3.

Chojnicki Z., 1999: Podstawy metodologiczne i teoretyczne geografii, Bogucki Wyd. Nauk., Poznań.

Ciszak O., Żurek J., 1998: Wyznaczanie kolejności montażu części i zespotów maszyn, Arch. Technologii Maszyn i Automatyzacji, Oddział PAN w Poznaniu, Vol. 18, nr. 2.

Deo N., 1974: Graph theory with applications to engineering and computer science. New Jersey. (Tłum. pol. 1980: Teoria grafów i jej zastosowanie w technice i informatyce. Warszawa).

Domański R., 1970: Syntetyczna charakterystyka obszaru na przykładzie okręgu przemystowego, Warszawa.

Domański R., 2000: Zasady geografii społeczno-ekonomicznej, Wyd. Nauk. PWN, Warszawa.

Ford Jr. L.R., Fulkerson D.R.F., 1962: Flows in networks, New Jersej (tłum. pol. 1969: Przepływy $w$ sieciach, Warszawa).

Garrison W.L., 1960: Connectivity of the Interstate Highway System, Reg. Sc. Association. Papers and Proceedings, 6.

Giaro K., 2003: Szeregowanie zadań metodami kolorowania grafów, Gdańsk.

Huk J., 1991: Wyznaczanie regionów migracyjnych w ujęciu systemowym, Act. Univ. Wratislaviensis, Stud. Geogr., 57.

Ignasiak E., 1982: Teoria grafów i planowanie sieciowe, Warszawa.

Jankowski B., 1998: Grafy. Algorytmy w Pascalu, Warszawa.

Kansky K.J., 1963: Structure of transport networks; relationships between network geometry and regional characteristics, Univ. of Chicago, Dep. of Geogr., Res. Papers.

Kissling C.C., 1969: Linkage importance in regional highway network, Canadian Geogr., 13.

Korzan B., 1978: Elementy teorii grafów i sieci. Metody i zastosowanie, Warszawa.

Koziarski S., 1990: Rozwój sieci kolejowej na Ślasku, Inst. Śląski, Opole.

Kulikowski J.L., 1986: Zarys teorii grafów, zastosowanie w technice, Warszawa.

Libura M., Sikorski J., 2002: Wykłady z matematyki dyskretnej. Cz. II: Teoria grafów, Warszawa.

Lityński J., 1969: Liczbowa klasyfikacja typów cyrkulacji i typów pogody dla Polski, Pr. PIHM, 97.

Maik W., 1976: Wyznaczanie hierarchii ośrodków centralnych metoda porzqdkowania wierzchotków w grafie, Spraw. PTPN, 91.

Marlewski A., 1989: Algebra i teoria grafów dla studentów politechnik, Poznań.

Muraco W.A., 1972: Interurban accessibility. Econ. Geogr., 48.

Öre O., 1963: Graphs and their uses, New York (tłum. pol. 1966: Wstęp do teorii grafów, Warszawa).

Palka Z., Ratajczak W., Weltrowska J., 2001: Wyznaczanie odległości między grafami. [W:] H. Rogacki (red.), Koncepcje teoretyczne i metody badań geografii społeczno-ekonomicznej i gospodarki przestrzennej, Bogucki Wyd. Nauk., Poznań.

Pulczyn W., 1968: Elementy teorii grafów, Warszawa.

Ratajczak W., 1980: Analiza i modele wpływu czynników społeczno-gospodarczych na ksztaltowanie się sieci transportowej, PAN Oddział w Poznaniu, Ser. Geogr., 5.

Rydzewski T., 1998: Dostęność kolejowa miast województwa szczecińskiego w 1994 roku, Zesz. Nauk. USz, nr 243, Marine Sc., No.5.

Rydzewski T., 1999: Dostępność autobusowa miast województwa szczecińskiego w 1998 roku, Zesz. Nauk. USz, nr 272, Marine Sc., No.6.

Rydzewski T., 2001: Dostępność topologiczna na przykładzie sieci kolejowej województwa za- 
chodniopomorskiego w 1999 roku. [W:] H. Rogacki (red.), Koncepcje teoretyczne i metody badań geografii społeczno-ekonomicznej i gospodarki przestrzennej. Poznań.

Stępniewska-Podrażka M., 1991: Kalendarz typów cyrkulacji atmosferycznej (1951-1990), IMGW, Warszawa.

Szamkołowicz L., 1971: Teoria grafów skończonych, Wrocław.

Taaffe E.J., Morrill R.L., Gould P.R., 1963: Transport expansion in undeveloped countries: a comparative analysis, Geogr. Rev., 53.

Tamulewicz J., 1982: Taksonomiczne podstawy typologii reżimu opadów atmosferycznych na przyktadzie Pojezierza Pomorskiego i Niziny Wielkopolskiej, Dok. Geogr., 3-4.

Tamulewicz J., 1992: Grafowa metoda badania struktury pól meteorologicznych - na przykładzie zachodniej części pola opadów Polski, Bad. Fizjogr. nad Polską Zach., t. XLIV, Ser. A, Geogr. Fiz..

Tamulewicz J., 1993: Struktura pola opadów atmosferycznych Polski w okresie 1951-1980, Wyd. Nauk. UAM, Poznań.

Taylor Z., 1975: Charakterystyka zmian w strukturze sieci transportowych w ujęciu grafowym, Przegl. Geogr., 47, z. 3.

Taylor Z., 1980: Zastosowanie metod grafowych do badania struktury sieci, Przegl. Zagr. Lit. Geogr., 4.

Warakomska K., 1992: Zagadnienie dostępności w geografii transportu, Przegl. Geogr., t. LXIV, z. $1-2$.

Weltrowska J., 2003: Rozwój przestrzenny systemu bankowego w Polsce w latach 1989-2002, Bogucki Wyd. Nauk., Poznań.

Werner C., 1969: Network of minimum length, Canadian Geogr., 13.

Wilson R.J., 2000: Wprowadzenie do teorii grafów, Warszawa.

Zagożdżon A., 1970: Metody grafowe w badaniach osadnictwa, Przegl. Geogr., 42, 2.

Zagożdżon A., 1977: Wykorzystanie metod i technik grafowych $w$ analizie struktur przestrzennych. [W:] Z.Chojnicki (red.), Metody ilościowe i modele w geografii, Warszawa. 